\title{
Influences of some pollutants on water quality of El-Bagouria Canal at Kafr El-Zayat Region, El-Gharbia Governorate, Egypt.
}

\author{
Mohamed H. Ghanem ${ }^{1}$; Emad H. Ghanem ${ }^{2}$; Sabry M. Shehata ${ }^{1}$; \\ Samir A. Zaahkouk ${ }^{1}$ and Ayman B. El-Amawy ${ }^{1}$ \\ 1- Department of Zoology, Faculty of Science, Al-Azhar University, Egypt. \\ 2- Faculty of Industrial Education, Beni Suef University, Egypt.
}

\section{ABSTRACT}

The present study aims to describe the effect of heavy metals: copper, manganese, iron and zinc on the water quality of El-Bagouria Canal at Kafr El-Zayat region, El-Gharbiah Governorate. Seasonal variations of physico-chemical parameters were studied during the period from summer, 2013 to spring, 2014. Also, to study their effects on the different organs of the commercial fish species; Nile tilapia, Oreochromis niloticus by studying some of biochemical parameters of this fish species (total protein, total lipids, total carbohydrates, ASAT and ALAT) during the study period.

Results revealed that, heavy metals in the water showed seasonal variations. Also, data exhibited the highest values of heavy metals in the different organs of $O$. niloticus were recorded during winter in the liver and kidney and the lowest were observed in the muscles. Biochemical analysis indicated devastating effects, especially enzymes activities, in the metabolic organs. Statistical analysis using analysis of variance (ANOVA, at $\mathrm{p}<0.05$ ) based on data represent the measured values of heavy metals in the different organs of $O$. niloticus during the different seasons. One way analysis proved that, there were highly significant differences between the metals and between the different seasons also between different organs. On the other hand, two ways of ANOVA provided highly significant differences between organs and metals at the same seasons. While, non-significant differences were detected at the interactions between seasons and organs at the same metals and between seasons and metals at the same organs. One way analysis for biochemical parameters in the different organs of $O$. niloticus during the different seasons proved that, there were highly significant differences between the parameters. Meanwhile, there were significant differences between the different seasons and between target organs. Moreover, two ways of ANOVA provided highly significant differences between organs and parameters at the same seasons. While, non-significant differences were found at the interactions between seasons and organs at the same parameters and between seasons and parameters at the same organs.

Keywords: Water quality, biochemical parameters, Oreochromis niloticus, El-Bagouria Canal, pollutant.

\section{INTRODUCTION}

Water always plays a central role as a source of life for all organisms. It is an input to almost all production, in agriculture, industry, energy, transport, by healthy people in healthy ecosystems (Grey and Sadoff, 2007). The River Nile travels along Egypt for about $940 \mathrm{~km}$ behind the High Dam. After passing Cairo, the Nile pursues a north westerly direction for about $23 \mathrm{~km}$ and divides at El-Kanater Barrage into two branches; Damietta and Rosetta branches and four Rayahs (Canals); El-Nassery, El-Behery, El-Menofy and El-Toufeky. Damietta Branch receives a large amount of 
untreated effluents from agricultural, domestic and partially treated industrial wastewater (Abdel-Aziz, 2005).

The average width and depth of Damietta Branch are 200 and 12 meter, respectively. It's the main source of drinking and irrigation waters for El-Qalyubia, El-Gharbia, El-Dakahlia and Damietta Governorates (Abdo, 2004). These branches are subjected to two sources of pollution. The first is a pointed source that refers to the contaminants that enter water way, such as sewage and industrial wastes. However, the second is non- pointed source that refers to contaminants that enter water way by diffusion such as agricultural, wastes (Kadry et al., 2015).

In El-Gharbia Governorate (central of Nile Delta), excessive use of sewage effluents and sludge, over-fertilization, over-use of manures for irrigation purposes cause hazard effects on plants, animals and human health. In addition, discharge of liquid and solid wastes with different contaminants into the environment causes groundwater deterioration (Zeidan et al., 2015). However, Kafr El-Zayat industrial area discharge industrial effluents from the factories of super phosphate and sulfur compounds, oil and soap industries and pesticides factories (Daboor, 2006). ElBagouria Canal is diverting from El-Monofy Rayah at km 21.3 it is $90.0 \mathrm{~km}$ long and it serves around 210,000 feddans. The whole length of the canal inside El-Gharbia

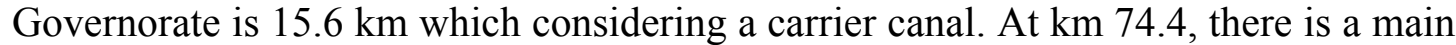
feeder to El-Bagouria Canal (Kafr El-Zayat Region) from the end of El-Melahia Canal (Tanta Region). Until the end of El-Monofiya directorate, the canal has two cross regulators; Shubrabas regulator (Km 29.8) and Kafr Rabie regulator ( $\mathrm{Km}$ 53.55) (El-Gammal, 2009).

The construction of canals and drains in the River Nile valley including its delta has attracted farmers to locate villages on the banks of the canals and to lesser extent drains. Both canals and drains have been polluted by discharge from these developing communities. Some canals and drains have been contaminated with heavy metals, pesticides, insecticides, fertilizers, possible domestic and industrial wastes, and other chemicals (Zaki et al., 2014). Water quality may be described in terms of the concentration and state the organic and inorganic material present in the water, together with certain physical characteristics of the water. The composition of surface waters is dependent on natural factors in the drainage basin and varies with seasonal differences in runoff volumes, weather conditions and water levels (Osman and Kloas, 2010). The Physico-chemical parameters are considered as the most important principles in the identification of the nature, quality and type of the water. The hardness of natural waters depends mainly on the presence of dissolved calcium and magnesium salts. Although, hardness (calcium carbonate) reduces the toxicity of divalent heavy metals, humic and fulvic acid, forms low toxicity complexes with some metals (Bujar et al., 2008 and Noor El-Deen et al., 2010). So, the increase of industry, agriculture urbanization and tourism, human activities are responsible for chemical pollution sources for the environment and aquatic ecosystems (Ashry et al., 2013).

Metal can be incorporated into food chains and concentrated in aquatic organisms to a level that affects their physiological state. Trace metals such as $\mathrm{Zn}, \mathrm{Cu}$ and Fe play a biochemical role in the life processes of all aquatic plants and animals. In the Egyptian irrigation system, the main sources are associated mainly with industrial and domestic effluents, urban storm, water runoff, landfill, atmospheric sources and inputs rural areas (Ciesielski et al, 2010). Long-term exposure to heavy metals by inhalation, ingestion and skin absorption may result in devastating effects on ecological balance of the recipient environment and a diversity of aquatic 
organisms plus slowly progressing physical, muscular and neurological degenerative processes (Otles \& Cagindi, 2010 and Suruchi \& Khanna, 2011).

Heavy metals like copper, iron and zinc are essential for fish metabolism, while some others such as mercury, cadmium and lead have no known role in biological systems. For normal metabolism the essential metals must be taken up from water or food, but excessive intake of the essential metals can produce toxic effects (Yousafzai, 2004).

Muscles are not always the best indicator of the entire body fish contaminations and therefore, it is vital to analyze other organs such as liver and kidney (HasSchon et al., 2006). Any stress factor may lead to an internal physiological disturbance in fish appears through changing in some blood features, disorder hormones and enzymes dysfunctions. Aspartate aminotransferase (ASAT) and alanine aminotransferase (ALAT) are important diagnostic tools in medicine and are used to detect adverse effects produced by various pollutants (Eddy, 2006). The increment of alanine aminotransferase and aspartate aminotransferase levels occurs nervous shock, hypoxia and stress where their plasma standard levels would be affected by several factors such as pollution, ammonia and nitrite toxications and other environmental parameters like temperature and salinity (Das et al., 2004). Furthermore, increasing or decreasing in the values of ALAT and ASAT indicating damage in the liver, kidney, muscles and gills (Ghanem, 2011).

Therefore, the present study aimed to evaluate the effect of water pollution on the physical and chemical parameters at Kafr El-Zayat regions represented in ElBagouria Canal during the period from summer, 2013 to spring, 2014. Also, to study the effect of some heavy metals (copper, manganese, iron and zinc) on the water of the canal and their bioaccumulation in the different organs of the commercial fish species; Nile tilapia (O. niloticus) by studying some biochemical parameters of this fish species (total proteins, total lipids, total carbohydrates, ASAT and ALAT) during the study period. Such investigations may lead to a better understanding of some environmental and physiological aspects.

\section{MATERIALS AND METHODS}

\section{Investigated area:}

The investigated area (El-Bagouria Canal) includes five stations along the west side of Kafr El-Zayat city; Hesset Abar village, Kalleeb Ebiar village, Kafr El-Zayat city, Kasr Nasr El-Din village and Akwa El-Hessah village (Fig. 1).

\section{Water analysis:}

\section{Collection of water samples:}

Water samples were collected (subsurface about $30 \mathrm{~cm}$ ) seasonally during the period from summer, 2013 to spring, 2014. A Van Dorn water sampler with capacity of 1.2 litters was used to obtain samples. After collection, water samples were kept in cleaned poly propylene bottles for latter examination; while some of physicochemical properties as (temperature, turbidity, $\mathrm{pH}$ and conductivity) were measured in the field during samples collection.

\section{Environmental Factors: \\ Water temperature:}

Water temperature was measured during collection of the samples using WTW instrument model 330i (Willard et al., 1974).

\section{Turbidity:}

Water turbidity was measured during the sampling time in 1 liter of each sample using WTW instrument model Turb.430T (APHA, 2005) after calibration with 
standard formazin solutions $(0.02,10$ and $1000 \mathrm{NTU})$; results were expressed as Nephelometric Turbidity Unit (NTU).

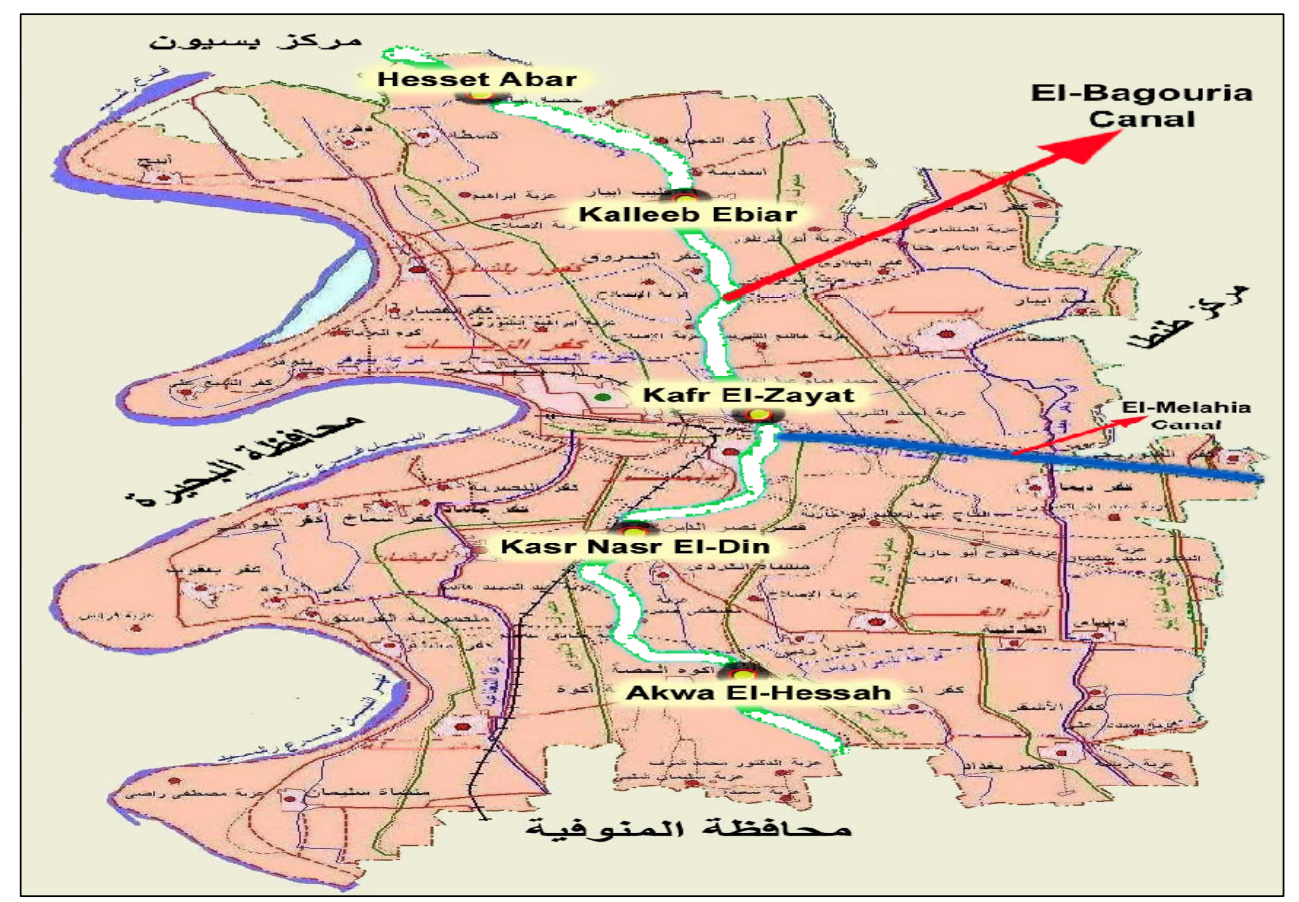

Fig. 1: Map of Kafr El-Zayat area showing the sampling stations in El-Bagouria Canal.

\section{Total dissolved solids (TDS):}

According to APHA (2012) conductivity was used to estimate total dissolved solids $(\mathrm{mg} / \mathrm{L})$ in a sample by multiplying conductivity (in micromhos per centimeter) by an empirical factor. This factor may vary from 0.55 to 0.9 , depending on the soluble components of the water and on the temperature of measurement.

The factor in the current method is 0.53 which attributed to calibration of conductivity meter by $0.01 \mathrm{M} \mathrm{KCl}$ solution.

$\operatorname{TDS}(\mathrm{mg} / \mathrm{L})=$ conductivity $\times 0.53$

\section{Electrical conductivity:}

It was measured immediately after sampling by using the conductivity meter WTW instrument (model 315i) calibrated with Potassium chloride solution (1413 $\mu \mathrm{S} / \mathrm{cm}$ ); Results were expressed as $\mu \mathrm{S} / \mathrm{cm}$ (Willard et al., 1974).

\section{Hydrogen ion concentration (pH):}

Hydrogen ion concentration $(\mathrm{pH})$ was measured directly after sampling using $\mathrm{pH}$ meter model (WTW 330i) after calibration with standard buffer solutions of $\mathrm{pH}$ 4,7 and 10 (APHA, 2005).

\section{Total hardness:}

Total hardness (calcium and magnesium) were determined by EDTA titrimetric method according to (APHA, 2005).

\section{Calcium:}

Calcium was determined by EDTA titrimetric method according to Katz and Navone (1964).

\section{Magnesium:}

Magnesium was estimated as the difference between hardness and calcium as CaCO3, according to APHA (2005). 


\section{Sodium:}

Flame Atomic Absorption model Varian AA240FS was used for determination sodium. The concentrations were deduced from calibration curve resulted from a series of standard sodium solutions (APHA, 2012).

Determination of heavy metals in water samples:

Heavy metals in the present study are; $\mathrm{Cu}, \mathrm{Mn}, \mathrm{Fe}$ and $\mathrm{Zn}$. Concentrations of heavy metals were determined after the digestion by nitric acid according to APHA (2012).

\section{Fish analysis:}

\section{Collection of fish samples:}

The selected species, Oreochromis niloticus (as a herbivore) was collected carefully from the canal during the study period.

\section{Determination of heavy metals in the fish organs:}

\section{Preparation of samples:}

Fish samples were stored in prewashed polyethylene bags and transferred immediately to the laboratory in ice box $\left(\right.$ at $4^{\circ} \mathrm{C}$ ). In the laboratory, fish were dissected and four organs (liver, kidney, muscles and gonads) were removed then an exact weight of each organ $(0.5 \mathrm{~g})$ was dried at $70^{\circ} \mathrm{C}$ to constant weight then placed in Teflon vessel and $5 \mathrm{ml}$ of analar nitric acid was added. The vessels were tightly covered and allowed to predigest at room temperature overnight. The digestion block was placed on a preheated hot plate at $80^{\circ} \mathrm{C}$ for three hours. Samples were cooled at room temperature and transferred to $25 \mathrm{ml}$ volumetric flask, and the volume was made up to $25 \mathrm{ml}$ of distilled water (UNEP, 1984)

Digested solutions were analyzed by using Atomic Absorption Spectrophotometer (model Varian AA240FS and AA240Z) according to APHA (2012).

\section{Biochemical analysis in the fish organs:}

Biochemical parameters in the present study are; total protein [TP], total lipids [TL], total carbohydrates [TC], Aspartate aminotransferase enzyme activity [ASAT] and Alanine aminotransferase enzyme activity [ALAT].

Fish were dissected and four organs (liver, kidney, muscle and gonads) were sepalated then an exact weight of each organ $(0.25 \mathrm{~g})$ was grinded through homogenizer in $4 \mathrm{ml}$ saline solution $(\mathrm{NaCl} 0.9 \%)$. Each sample was centrifuged at 4000 round for 15 minutes, the supernatant were transferred to clean wasserman tube and measured according to each parameter kit pamphlet.

\section{Determination of the total protein:}

Total protein contents were determined using Diamond commercial colorimetric kits according to Burtis and Ashwood (1999). Results were converted to mg/g wet wt.

\section{Determination of the total lipids:}

Total lipids content of the different organs was determined using $\mathrm{ABC}$ commercial colorimetric kits by rapid colorimetric method according to Tietz (1976). Results were converted to $\mathrm{mg} / \mathrm{g}$ wet wt.

Determination of the total carbohydrates:

Total carbohydrate content of the different organs was determined according to Frolund et al. (1996). Results were converted to $\mathrm{mg} / \mathrm{g}$ wet wt.

\section{Determination of ASAT and ALAT activities:}

The activities of ASAT and ALAT were estimated by spectrum kit. Kinetic method according to the International Federation of Clinical Chemistry (IFCC, 1986). Results were converted to U/g wet wt. 


\section{Statistical analysis:}

Results were expressed in tables as mean \pm S.D. Data were analyzed by using analysis of variance (ANOVA) according to Bailey (1981).

\section{RESULTS AND DISCUSSION}

\section{Environmental factors (Physico-chemical parameters): Water temperature:}

Temperature is the water quality indicator that exhibited little variance between the sites and showed clear seasonal variations. The changes of water temperature may depend on the variations in meteorological conditions, air temperature, latent heat of evaporation and different sampling times and seasons (Abdel-Satar, 2005 and Ahmed, 2012).

Data (Table 1) revealed that, water temperature at El-Bagouria Canal (Kafr ElZayat Region) was peaked at Kafr El-Zayat city during summer $\left(29.23 \pm 0.25^{\circ} \mathrm{C}\right)$ and declined at Hesset Abar village during winter $\left(17.1 \pm 0.1{ }^{\circ} \mathrm{C}\right)$. The results were in agreement with those obtained by Ezzat et al. (2012) and Kadry et al. (2015), who concluded that, the variation in water temperature depends mainly on the climatic conditions, sampling times, the number of sunshine hours and also affected by specific characteristics of water environment such as turbidity, wind force, plant cover and humidity.

\section{Turbidity of water:}

Turbidity is an indicator of the amount of material suspended in water; it measures the amount of light that is scattered or absorbed. Suspended silt and clay, organic matter as well as plankton can contribute to turbidity. It decreases the light penetration, limits the production of phytoplankton, which in consequence decreases the photosynthetic activity and depletion of oxygen content. It restricts the light penetration in water, resulting in reduced primary production (Siddaramu and Puttaiah, 2013).

The present data declared that, the maximum value of turbidity in the water was recorded during spring at Kalleeb Ebiar village (12.3 $\pm 0.1 \mathrm{NTU})$ and the minimum one $(2.62 \pm 0.01 \mathrm{NTU})$ occurred during summer at Akwa El-Hessah village (Table 1). These results may be due to sampling location, particularly at the industrial sites of Kafr El-Zayat. This elevation in the turbidity during spring may be attributed to the effect of the prevailing wind which helps in mixing water and stirring up the sediment. Similar observations were obtained by Moustafa et al. (2010) and Ashry et al. (2013) and differed with Ezzat et al. (2012) and Al-Obaidy et al. (2015) who observed the highest turbidity during summer.

\section{Total dissolved solids:}

Total dissolved solids are composed mainly of carbonates, bicarbonates, chlorides, phosphates and nitrates of calcium, magnesium, sodium, potassium and manganese, organic matter, salt and other particles (Mahananda, 2010).

The present results (Table 1) showed that, the maximal value of total dissolved solids in the water of El-Bagouria Canal was recorded during winter at Hesset Abar and Kalleeb Ebiar stations $(229 \pm 1.0 \mathrm{mg} / \mathrm{L})$ and the minimal value occurred during spring at Kasr Nasr El-Din Bridge $(191 \pm 1.0 \mathrm{mg} / \mathrm{L})$. This may be attributed to the elevation of water salts during winter as a result of blocking period. The present observations were nearly agree with these obtained by El-Bouraie et al. (2011) and differ with Abdel-Hamid et al. (2013) who postulated the minimum value of TDS 
during winter, in addition to Khallaf et al. (2014) who recorded the highest TDS during spring.

Table 1: Seasonal variations of some physical - chemical parameters in the surface water at the different stations of El-Bagouria Canal, Kafr El-Zayat, during the period of study.

\begin{tabular}{|c|c|c|c|c|c|c|c|c|c|c|c|c|c|c|c|c|c|c|c|c|}
\hline Parameters & \multicolumn{4}{|c|}{ Water temperature $\left({ }^{\circ} \mathrm{C}\right)$} & \multicolumn{4}{|c|}{ Turbidity (NTU) } & \multicolumn{4}{|c|}{ Total dissolved solid (mg/L) } & \multicolumn{4}{|c|}{ Electric conductivity $(\mu \mathrm{S} / \mathrm{cm})$} & \multicolumn{4}{|c|}{$\mathrm{pH}$ value } \\
\hline Stations & 壱 & $\underline{E}$ & 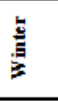 & 晃 &  & 言 & 音 & 最 & 昱 & 恶 & 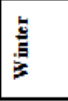 & 葛 & E & 产 & 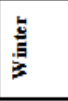 & 最 & 馬 & 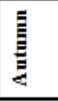 & 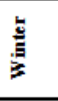 & 管 \\
\hline تُ & $\begin{array}{l}27.90 \\
\pm 0.10\end{array}$ & $\begin{array}{l}20.80 \\
\pm 0.10\end{array}$ & $\begin{array}{l}17.10 \\
\pm .10\end{array}$ & $\begin{array}{l}26.00 \\
\pm 0.10\end{array}$ & $\begin{array}{c}3.39 \\
\pm 0.02\end{array}$ & $\begin{array}{c}3.72 \\
\pm 0.02\end{array}$ & $\begin{array}{c}5.30 \\
\pm 0.03\end{array}$ & $\begin{array}{c}9.07 \\
\pm 0.02\end{array}$ & $\begin{array}{r}204.00 \\
\pm 1.00\end{array}$ & $\begin{array}{l}226.00 \\
\pm 1.00\end{array}$ & $\begin{array}{l}229.00 \\
\pm 1.00\end{array}$ & $\begin{array}{l}194.00 \\
\pm 1.00\end{array}$ & $\begin{array}{l}383.33 \\
\pm 0.58\end{array}$ & $\begin{array}{l}426.00 \\
\pm 1.00\end{array}$ & $\begin{array}{l}433.00 \\
\pm 2.00\end{array}$ & $\begin{array}{l}365.00 \\
\pm 1.00\end{array}$ & $\begin{array}{l}7.66 \\
\pm .01\end{array}$ & $\begin{array}{c}7.77 \\
\pm 0.01\end{array}$ & $\begin{array}{c}7.97 \\
\pm 0.02\end{array}$ & $\begin{array}{c}7.91 \\
\pm 0.02\end{array}$ \\
\hline 戈 & $\begin{array}{l}28.43 \\
\pm 0.06\end{array}$ & $\begin{array}{l}21.00 \\
\pm 1.00\end{array}$ & $\begin{array}{l}17.40 \\
\pm 0.10\end{array}$ & $\begin{array}{l}26.50 \\
\pm 0.10\end{array}$ & $\begin{array}{c}4.14 \\
\pm 0.01\end{array}$ & $\begin{array}{c}4.45 \\
\pm 0.01\end{array}$ & $\begin{array}{c}7.13 \\
\pm 0.01\end{array}$ & $\begin{array}{l}12.30 \\
\pm 0.10\end{array}$ & $\begin{array}{l}203.33 \\
\pm 0.58\end{array}$ & $\begin{array}{l}225.00 \\
\pm 1.00\end{array}$ & $\begin{array}{l}229.00 \\
\pm 1.00\end{array}$ & $\begin{array}{l}194.00 \\
\pm 1.00\end{array}$ & $\begin{array}{l}383.33 \\
\pm 0.58\end{array}$ & $\begin{array}{l}426.00 \\
\pm 1.00\end{array}$ & $\begin{array}{l}432.00 \\
\pm 2.00\end{array}$ & $\begin{array}{l}366.00 \\
\pm 1.00\end{array}$ & $\begin{array}{c}7.67 \\
\pm 0.01\end{array}$ & $\begin{array}{c}7.79 \\
\pm 0.02\end{array}$ & $\begin{array}{c}7.99 \\
\pm 0.02\end{array}$ & $\begin{array}{c}8.07 \\
\pm 0.02\end{array}$ \\
\hline 苟营 & $\begin{array}{l}29.23 \\
\pm 0.25\end{array}$ & $\begin{array}{l}21.60 \\
\pm 0.20\end{array}$ & $\begin{array}{l}17.70 \\
\pm 0.10\end{array}$ & $\begin{array}{l}25.30 \\
\pm 1.56\end{array}$ & $\begin{array}{c}2.66 \\
\pm 0.01\end{array}$ & $\begin{array}{c}3.24 \\
\pm 0.04\end{array}$ & $\begin{array}{l}4.61 \\
\pm .01\end{array}$ & $\begin{array}{l}10.00 \\
\pm 0.20\end{array}$ & $\begin{array}{l}206.33 \\
\pm 0.58\end{array}$ & $\begin{array}{l}224.00 \\
\pm 1.00\end{array}$ & $\begin{array}{l}227.00 \\
\pm 1.00\end{array}$ & $\begin{array}{l}194.00 \\
\pm 1.00\end{array}$ & $\begin{array}{l}389.33 \\
\pm 0.58\end{array}$ & $\begin{array}{l}423.00 \\
\pm 1.00\end{array}$ & $\begin{array}{l}428.00 \\
\pm 2.00\end{array}$ & $\begin{array}{l}366.00 \\
\pm 1.00\end{array}$ & $\begin{array}{c}7.69 \\
\pm 0.01\end{array}$ & $\begin{array}{c}7.82 \\
\pm 0.02\end{array}$ & $\begin{array}{c}8.09 \\
\pm 0.01\end{array}$ & $\begin{array}{c}8.08 \\
\pm 0.02\end{array}$ \\
\hline  & $\begin{array}{l}28.60 \\
\pm 0.10\end{array}$ & $\begin{array}{l}21.40 \\
\pm 0.10\end{array}$ & $\begin{array}{l}17.90 \\
\pm 0.20\end{array}$ & $\begin{array}{l}26.60 \\
\pm 0.10\end{array}$ & $\begin{array}{c}4.13 \\
\pm 0.02\end{array}$ & $\begin{array}{r}3.48 \\
\pm 0.02\end{array}$ & $\begin{array}{c}5.38 \\
\pm 0.02\end{array}$ & $\begin{array}{l}11.50 \\
\pm 0.20\end{array}$ & $\begin{array}{l}205.33 \\
\pm 0.58\end{array}$ & $\begin{array}{l}226.00 \\
\pm 1.00\end{array}$ & $\begin{array}{l}228.00 \\
\pm 1.00\end{array}$ & $\begin{array}{l}191.00 \\
\pm 1.00\end{array}$ & $\begin{array}{c}387.33 \\
\pm 0.58\end{array}$ & $\begin{array}{l}427.00 \\
\pm 1.00\end{array}$ & $\begin{array}{l}430.00 \\
\pm 1.00\end{array}$ & $\begin{array}{l}362.00 \\
\pm 1.00\end{array}$ & $\begin{array}{c}7.64 \\
\pm 0.01\end{array}$ & $\begin{array}{c}7.88 \\
\pm 0.02\end{array}$ & $\begin{array}{c}8.09 \\
\pm 0.02\end{array}$ & $\begin{array}{c}8.23 \\
\pm 0.03\end{array}$ \\
\hline  & $\begin{array}{l}28.73 \\
\pm 0.06\end{array}$ & $\begin{array}{l}21.30 \\
\pm 0.10\end{array}$ & $\begin{array}{l}17.70 \\
\pm 0.10\end{array}$ & $\begin{array}{l}26.40 \\
\pm 0.02\end{array}$ & $\begin{array}{c}2.62 \\
\pm 0.01\end{array}$ & $\begin{array}{c}3.75 \\
\pm 0.05\end{array}$ & $\begin{array}{c}4.80 \\
\pm 0.05\end{array}$ & $\begin{array}{c}9.41 \\
\pm 0.02\end{array}$ & $\begin{array}{l}205.33 \\
\pm 0.58\end{array}$ & $\begin{array}{l}225.00 \\
\pm 1.00\end{array}$ & $\begin{array}{l}228.00 \\
\pm 2.00\end{array}$ & $\begin{array}{l}192.00 \\
\pm 1.00\end{array}$ & $\begin{array}{l}386.33 \\
\pm 0.58\end{array}$ & $\begin{array}{l}425.00 \\
\pm 1.00\end{array}$ & $\begin{array}{l}431.00 \\
\pm 2.00\end{array}$ & $\begin{array}{l}362.00 \\
\pm 1.00\end{array}$ & $\begin{array}{c}7.61 \\
\pm 0.01\end{array}$ & $\begin{array}{c}7.91 \\
\pm 0.02\end{array}$ & $\begin{array}{c}8.06 \\
\pm 0.03\end{array}$ & $\begin{array}{c}8.23 \\
\pm 0.02\end{array}$ \\
\hline
\end{tabular}

\section{Electric conductivity:}

The conductivity increased with the increasing of total dissolved solids and water temperature (Entz, 1973). The present results indicated that, the high peak of electrical conductivity in the water was recorded during winter at Hesset Abar village $(433 \pm 2.0 \mu \mathrm{S} / \mathrm{cm})$ and the lower one $(362 \pm 1.0 \mu \mathrm{S} / \mathrm{cm})$ occurred during spring at Kasr Nasr El-Din and Akwa El-Hessah stations (Table 1). The explanation of conductivity variance depend on the concentration of total solids and ions however, high conductivity during winter may be attributed to stagnation of water and decrease of water level in the River Nile during the closing period of High Dam gates. The present findings are completely agreed with Al-Obaidy et al. (2015). While, the differed observations were obtained by Khallaf et al. (2014) who recorded the lowest conductivity during winter.

\section{Hydrogen ion concentration (pH):}

Hydrogen ion concentration $(\mathrm{pH})$ is the master control parameter in aquatic environment for the chemical and biological transformation of water (Goher, 2002).

Results (Table 1) revealed that, hydrogen ion concentration varied from $7.61 \pm$ 0.01 during summer at Akwa El-Hessah village to $8.23 \pm 0.03$ during spring at Kasr Nasr El-Din and Akwa El-Hessah stations. This increasing in $\mathrm{pH}$ value may be related to photosynthesis and growth of aquatic plants, where photosynthesis consumes $\mathrm{CO}_{2}$ leading to arise in $\mathrm{pH}$ values. These results are agreed with Khallaf et al. (2014) and El-Otify \& Iskaros (2015) while they differed with Daifullah et al. (2003) and Ghannam et al. (2014) who recorded the highest value of $\mathrm{pH}$ during summer and the lowest one during winter.

\section{Total hardness:}

Total hardness in the water was declined from $156 \pm 2.0 \mathrm{mg} / \mathrm{L}$ at Hesset Abar, Kalleeb Ebiar and Kafr El-Zayat stations during autumn to $132 \pm 2.0 \mathrm{mg} / \mathrm{L}$ at Kafr ElZayat and Kasr Nasr El-Din stations during spring (Table 2). 
Table 2: Seasonal variations of total hardness, calcium, magnesium and sodium in the surface water at the different stations of El-Bagouria Canal, Kafr El-Zayat, during the period of study.

\begin{tabular}{|c|c|c|c|c|c|c|c|c|c|c|c|c|c|c|c|c|}
\hline Parameters & \multicolumn{4}{|c|}{ Total hardness ( $\mathrm{mg} / \mathrm{L}$ ) } & \multicolumn{4}{|c|}{ Calcium ( $\mathrm{mg} / \mathrm{L})$} & \multicolumn{4}{|c|}{ Magnesium ( $\mathrm{mg} / \mathrm{L}$ ) } & \multicolumn{4}{|c|}{ Sodium ( $\mathrm{mg} / \mathrm{L})$} \\
\hline Stations & 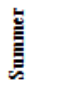 & $\underline{E}$ & 站 & 㣢 & 童 & 亘 & 欮 & 嫼 & 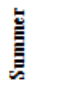 & $\underline{\underline{E}}$ & 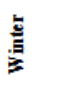 & 影 & 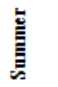 & $\underline{E}$ & 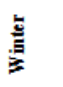 & 兽 \\
\hline 竎 & $\begin{array}{l}143.33 \\
\pm 1.15\end{array}$ & $\begin{array}{l}156.00 \\
\pm 2.00\end{array}$ & $\begin{array}{l}140.00 \\
\pm 2.00\end{array}$ & $\begin{array}{l}136.00 \\
\pm 2.00\end{array}$ & $\begin{array}{c}37.94 \\
\pm 0.46\end{array}$ & $\begin{array}{c}38.48 \\
\pm 0.80\end{array}$ & $\begin{array}{r}34.47 \\
\pm 0.80\end{array}$ & $\begin{array}{r}32.87 \\
\pm 0.80\end{array}$ & $\begin{array}{l}11.84 \\
\pm 0.56\end{array}$ & $\begin{array}{l}14.59 \\
\pm 0.49\end{array}$ & $\begin{array}{l}13.13 \\
\pm 0.97\end{array}$ & $\begin{array}{l}13.13 \\
\pm 0.97\end{array}$ & $\begin{array}{l}25.67 \\
\pm 0.58\end{array}$ & $\begin{array}{l}26.67 \\
\pm 0.71\end{array}$ & $\begin{array}{l}23.67 \\
\pm 0.89\end{array}$ & $\begin{array}{l}21.00 \\
\pm 0.31\end{array}$ \\
\hline 氙 & $\begin{array}{l}139.33 \\
\pm 1.15\end{array}$ & $\begin{array}{l}156.00 \\
\pm 2.00\end{array}$ & $\begin{array}{l}138.00 \\
\pm \mathbf{2 . 0 0}\end{array}$ & $\begin{array}{l}138.00 \\
\pm 2.00\end{array}$ & $\begin{array}{l}36.61 \\
\pm 0.46\end{array}$ & $\begin{array}{l}39.28 \\
\pm 0.80\end{array}$ & $\begin{array}{l}35.27 \\
\pm 0.80\end{array}$ & $\begin{array}{l}33.67 \\
\pm 0.80\end{array}$ & $\begin{array}{l}11.67 \\
\pm 0.49\end{array}$ & $\begin{array}{l}14.11 \\
\pm 0.97\end{array}$ & $\begin{array}{l}12.16 \\
\pm 0.84\end{array}$ & $\begin{array}{l}13.13 \\
\pm 0.97\end{array}$ & $\begin{array}{l}\mathbf{5 6 . 0 0} \\
\pm 1.00\end{array}$ & $\begin{array}{l}26.33 \\
\pm 0.58\end{array}$ & $\begin{array}{l}21.67 \\
\pm 1.53\end{array}$ & $\begin{array}{l}21.67 \\
\pm 0.80\end{array}$ \\
\hline  & $\begin{array}{l}145.33 \\
\pm 1.15\end{array}$ & $\begin{array}{l}156.00 \\
\pm 2.00\end{array}$ & $\begin{array}{l}144.00 \\
\pm 2.00\end{array}$ & $\begin{array}{l}132.00 \\
\pm 2.00\end{array}$ & $\begin{array}{l}36.61 \\
\pm 0.46\end{array}$ & $\begin{array}{l}38.48 \\
\pm 0.80\end{array}$ & $\begin{array}{l}33.67 \\
\pm 0.80\end{array}$ & $\begin{array}{l}33.67 \\
\pm 0.80\end{array}$ & $\begin{array}{l}13.13 \\
\pm 0.05\end{array}$ & $\begin{array}{l}14.59 \\
\pm 0.84\end{array}$ & $\begin{array}{l}14.59 \\
\pm 0.03\end{array}$ & $\begin{array}{l}11.67 \\
\pm 0.49\end{array}$ & $\begin{array}{l}\mathbf{2 6 . 0 0} \\
\pm 1.32\end{array}$ & $\begin{array}{l}26.33 \\
\pm 0.78\end{array}$ & $\begin{array}{l}22.00 \\
\pm 1.73\end{array}$ & $\begin{array}{l}22.00 \\
\pm 1.00\end{array}$ \\
\hline 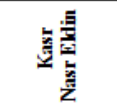 & $\begin{array}{l}147.33 \\
\pm 1.15\end{array}$ & $\begin{array}{l}154.00 \\
\pm 2.00\end{array}$ & $\begin{array}{l}144.00 \\
\pm 2.00\end{array}$ & $\begin{array}{l}132.00 \\
\pm 2.00\end{array}$ & $\begin{array}{l}36.61 \\
\pm 0.46\end{array}$ & $\begin{array}{l}38.48 \\
\pm 0.80\end{array}$ & $\begin{array}{r}34.47 \\
\pm 0.80\end{array}$ & $\begin{array}{l}33.67 \\
\pm 0.80\end{array}$ & $\begin{array}{l}13.62 \\
\pm 0.49\end{array}$ & $\begin{array}{l}14.11 \\
\pm 0.08\end{array}$ & $\begin{array}{l}14.11 \\
\pm 0.84\end{array}$ & $\begin{array}{l}11.67 \\
\pm 0.07\end{array}$ & $\begin{array}{l}26.00 \\
\pm 1.22\end{array}$ & $\begin{array}{l}27.33 \\
\pm 0.67\end{array}$ & $\begin{array}{l}20.67 \\
\pm 0.58\end{array}$ & $\begin{array}{l}21.33 \\
\pm 1.19\end{array}$ \\
\hline 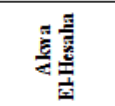 & $\begin{array}{l}146.67 \\
\pm 1.15\end{array}$ & $\begin{array}{l}154.00 \\
\pm 2.00\end{array}$ & $\begin{array}{l}146.00 \\
\pm 2.00\end{array}$ & $\begin{array}{l}134.00 \\
\pm 2.00\end{array}$ & $\begin{array}{l}36.61 \\
\pm 0.46\end{array}$ & $\begin{array}{l}37.68 \\
\pm 0.80\end{array}$ & $\begin{array}{l}34.47 \\
\pm 0.80\end{array}$ & $\begin{array}{l}33.67 \\
\pm 0.80\end{array}$ & $\begin{array}{l}13.46 \\
\pm 0.82\end{array}$ & $\begin{array}{l}14.59 \\
\pm 0.02\end{array}$ & $\begin{array}{l}14.59 \\
\pm 0.97\end{array}$ & $\begin{array}{l}12.16 \\
\pm 0.49\end{array}$ & $\begin{array}{l}25.67 \\
\pm 1.37\end{array}$ & $\begin{array}{l}28.67 \\
\pm 0.63\end{array}$ & $\begin{array}{l}20.67 \\
\pm 0.71\end{array}$ & $\begin{array}{l}19.67 \\
\pm 0.58\end{array}$ \\
\hline
\end{tabular}

Study area showed visible variations in total hardness. This may be due to the sum of the calcium and magnesium concentrations, expressed as calcium carbonate that may be elevated because of effluents of industrial wastes which decrease $\mathrm{pH}$ and facilitate carbonate dissolving. Similar observations were recorded by Abdel-Hamid et al. (2013) and Khallaf et al. (2014) and disagreed with Emara et al. (2012) and Hassanein et al. (2013) who revealed the maximum value of total hardness during winter.

\section{Calcium:}

Calcium compounds are widely used in pharmaceuticals, photography, lime, deicing salts, pigments, fertilizers, and plasters. Calcium carbonate solubility is controlled by $\mathrm{pH}$ and dissolved $\mathrm{CO}_{2}$ (APHA, 2012).

Results (Table 2) declared that, calcium concentration in the water was fluctuated between $32.87 \pm 0.8 \mathrm{mg} / \mathrm{L}$ at Hesset Abar village during spring and $39.28 \pm$ $0.8 \mathrm{mg} / \mathrm{L}$ at Kalleeb Ebiar village during autumn. The present study showed that, the increasing in calcium content is described by rising in water temperature which may lead to the increasing rate of decomposition of organic matter in sediment by bacterial action releasing the breakdown products including cations. While, decreasing in calcium content could be explained on the basis of its uptake by aquatic microorganisms and fishes. These observations were nearly similar to those notably by Emara et al. (2012) and Khallaf et al. (2014) who found the lowest concentration of calcium during spring and differed with Abdel-Satar (2005) and Ezzat et al. (2012) who reported the highest calcium during summer.

\section{Magnesium:}

Magnesium is one of the most important macro-element essential for all chlorophyll containing organisms. It plays an important role in photosynthesis, where give active center in the chlorophyll molecule (El-Enani, 2004).

Data (Table 2) exhibited the maximum concentrations of magnesium ion in the water $(14.59 \pm 0.97 \mathrm{mg} / \mathrm{L})$ during winter at Akwa El-Hessah village and the minimum one $(11.67 \pm 0.07 \mathrm{mg} / \mathrm{L})$ occurred during spring at Kasr Nasr El-Din village. Lower magnesium concentration than calcium may be due to supremacy of calcium ions over magnesium ions in sedimentary rocks which could release $\mathrm{Mg}^{+2}$ in the water stream as 
a result of effluents with low $\mathrm{pH}$. The present findings are in agreement with AbdelSatar (2005) and El-Otify \& Iskaros (2015). While, Ezzat et al. (2012) was in contrast with current study by recording the highest magnesium during autumn and the lowest during winter. Also, Khallaf et al. (2014) showed the maximum magnesium value during spring and the minimum during summer.

\section{Sodium:}

Sodium salts are highly soluble in the water and hence all natural waters contain a little amount of sodium (Roberts and Marsh, 1987).

Results (Table 2) indicated that, sodium in the water was peaked during summer at Kalleeb Ebiar village $(56 \pm 1.0 \mathrm{mg} / \mathrm{L})$ and declined during spring at Akwa El-Hessah village $(19.67 \pm 0.58 \mathrm{mg} / \mathrm{L})$. This elevation of sodium concentration at Kalleeb Ebiar village during summer might be due to the high mobility of sodium ion and dominates in the natural solutions in the form of effluents near sampling site. The obtained results are in agreement with Ravindra et al. (2003) and Ezzat et al. (2012). Meanwhile, they are in contrast with Chandra et al. (2006) and Hassanein et al. (2013) who found the highest concentration of sodium during winter.

Analysis of variance (one way) proved that, there are highly significant differences between the different seasons and between parameters on the values of environmental factors. On the other hand, two ways of ANOVA showed that, the interactions between the different seasons and parameters were highly significant (Table 2).

\section{Heavy metals:}

Water samples:

Heavy metal pollution in air, water, soil and plant systems is one of major environmental concern on a world scale with the rapid development of the industry. Beside their natural occurrence, heavy metals may enter the ecological system through anthropogenic activities such as sewage sludge disposal, application of pesticides and inorganic fertilizers as well as atmospheric deposition (Haiyan and Stuanes, 2003).

\section{Copper:}

Copper is considered an essential trace element for plants and animals. Some compounds are toxic by ingestion or inhalation. The United Nations Food and Agriculture Organization recommended maximum level for irrigation waters is 200 $\mu \mathrm{g} / \mathrm{L}$ (APHA, 2012).

Copper concentration in the water attained its high peak during summer at Kasr Nasr El-Din village $(24.67 \pm 5.51 \mu \mathrm{g} / \mathrm{L})$ and the lowest one $(3.00 \pm 1.00 \mu \mathrm{g} / \mathrm{L})$ during spring at Kafr El-Zayat City (Table 3). These seasonal variations may be due to the fluctuation of the amount of agricultural drainage water and sewage effluents discharged into the canal. Similar observations were obtained by Daifullah et al. (2003) and didn't match with the results of Moustafa et al. (2010) and Alawy et al. (2015) who obtained the highest level of copper during spring and the lowest level during autumn.

Manganese:

It is present in aquatic ecosystem in many oxidation states. Moreover, manganese is unstable in oxygenated water and easily to oxidized to higher most stable state with formation of solids $\mathrm{MnO}_{2}$ (Ghallab, 2000).

The maximal value of manganese in the water was recorded at Kalleeb Ebiar village during spring $(178.30 \pm 24.30 \mu \mathrm{g} / \mathrm{L})$ and the lowest one $(11.33 \pm 2.31 \mu \mathrm{g} / \mathrm{L})$ occurred during autumn at Hesset Abar village (Table 3). This elevation of manganese during spring may be attributed to the effect of the drought period with probable 
presence of industrial effluents. These observations were in agreement with Venkatesha et al. (2013) and differed with Ibrahim and Omar (2013) who recorded the higher values of manganese during summer and the lowest one during winter.

Table 3: Seasonal variations of copper, manganese, iron and zinc in the surface water at the different stations of Bagouria Canal, Kafr El-Zayat, during the period of study.

\begin{tabular}{|c|c|c|c|c|c|c|c|c|c|c|c|c|c|c|c|c|}
\hline Parameters & \multicolumn{4}{|c|}{ Copper $(\mu \mathrm{g} / \mathrm{L})$} & \multicolumn{4}{|c|}{ Manganese $(\mu \mathrm{g} / \mathrm{L})$} & \multicolumn{4}{|c|}{ Iron $(\mu \mathrm{g} / \mathrm{L})$} & \multicolumn{4}{|c|}{$\operatorname{Zinc}(\mu \mathrm{g} / \mathrm{L})$} \\
\hline Station & 昱 & 咅 & 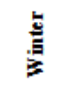 & 产 & 产 & 产 & 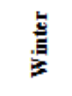 & 兽 & 萻 & 帝 & 总 & 章 & 昱 & 咅 &  & 晃 \\
\hline 吾 & $\begin{array}{r}18.00 \\
\pm 0.61\end{array}$ & $\begin{array}{c}5.33 \\
\pm 0.58\end{array}$ & $\begin{array}{c}5.67 \\
\pm 0.58\end{array}$ & $\begin{array}{c}6.00 \\
\pm 0.05\end{array}$ & $\begin{array}{c}29.00 \\
\pm 11.14\end{array}$ & $\begin{array}{r}11.33 \\
\pm 2.31\end{array}$ & $\begin{array}{r}70.00 \\
\pm 7.81\end{array}$ & $\begin{array}{l}164.33 \\
\pm 6.04\end{array}$ & $\begin{array}{r}203.33 \\
\pm 15.28\end{array}$ & $\begin{array}{c}73.33 \\
\pm 20.82\end{array}$ & $\begin{array}{l}113.33 \\
\pm 5.77\end{array}$ & $\begin{array}{c}906.67 \\
\pm 15.28\end{array}$ & $\begin{array}{l}21.00 \\
\pm 6.24\end{array}$ & $\begin{array}{c}4.50 \\
\pm 0.87\end{array}$ & $\begin{array}{c}5.43 \\
\pm 0.40\end{array}$ & $\begin{array}{c}\mathbf{5 . 3 0} \\
\pm 0.26\end{array}$ \\
\hline 홀 & $\begin{array}{r}13.00 \\
\pm 5.29\end{array}$ & $\begin{array}{r}4.33 \\
\pm .53\end{array}$ & $\begin{array}{c}5.37 \\
\pm 0.47\end{array}$ & $\begin{array}{c}\mathbf{5 . 7 7} \\
\pm 0.23\end{array}$ & $\begin{array}{r}32.60 \\
\pm 8.50\end{array}$ & $\begin{array}{r}13.13 \\
\pm 2.71\end{array}$ & $\begin{array}{c}81.00 \\
\pm 6.56\end{array}$ & $\begin{array}{c}178.30 \\
\pm 24.30\end{array}$ & $\begin{array}{l}176.67 \\
\pm 5.77\end{array}$ & $\begin{array}{c}60.00 \\
\pm 10.00\end{array}$ & $\begin{array}{l}186.67 \\
\pm 5.77\end{array}$ & $\begin{array}{l}980.00 \\
\pm 62.45\end{array}$ & $\begin{array}{c}4.33 \\
\pm 0.58\end{array}$ & $\begin{array}{c}4.67 \\
\pm 0.58\end{array}$ & $\begin{array}{c}5.17 \\
\pm 0.29\end{array}$ & $\begin{array}{c}5.00 \\
\pm 0.81\end{array}$ \\
\hline 롳 & $\begin{array}{l}18.33 \\
\pm 2.08\end{array}$ & $\begin{array}{c}5.33 \\
\pm 0.58\end{array}$ & $\begin{array}{c}5.87 \\
\pm 0.15\end{array}$ & $\begin{array}{c}3.00 \\
\pm 1.00\end{array}$ & $\begin{array}{c}21.33 \\
\pm 3.05\end{array}$ & $\begin{array}{c}12.90 \\
\pm 2.54\end{array}$ & $\begin{array}{c}80.67 \\
\pm 7.23\end{array}$ & $\begin{array}{l}160.50 \\
\pm 1.14\end{array}$ & $\begin{array}{r}123.33 \\
\pm 49.33\end{array}$ & $\begin{array}{c}43.33 \\
\pm 32.15\end{array}$ & $\begin{array}{c}130.00 \\
\pm 34.64\end{array}$ & $\begin{array}{l}1156.67 \\
\pm 77.67\end{array}$ & $\begin{array}{c}5.00 \\
\pm 0.31\end{array}$ & $\begin{array}{c}5.00 \\
\pm 0.50\end{array}$ & $\begin{array}{c}5.33 \\
\pm 0.29\end{array}$ & $\begin{array}{c}5.43 \\
\pm 0.21\end{array}$ \\
\hline 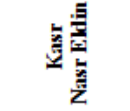 & $\begin{array}{r}24.67 \\
\pm 5.51\end{array}$ & $\begin{array}{r}6.00 \\
\pm .02\end{array}$ & $\begin{array}{c}5.70 \\
\pm 0.26\end{array}$ & $\begin{array}{c}3.67 \\
\pm 1.15\end{array}$ & $\begin{array}{c}23.00 \\
\pm 4.00\end{array}$ & $\begin{array}{c}14.23 \\
\pm 0.40\end{array}$ & $\begin{array}{c}85.67 \\
\pm 7.02\end{array}$ & $\begin{array}{l}113.87 \\
\pm 6.61\end{array}$ & $\begin{array}{r}180.00 \\
\pm 20.00\end{array}$ & $\begin{array}{c}33.33 \\
\pm 5.77\end{array}$ & $\begin{array}{c}180.00 \\
\pm 10.00\end{array}$ & $\begin{array}{c}540.00 \\
\pm 10.00\end{array}$ & $\begin{array}{c}5.00 \\
\pm 0.72\end{array}$ & $\begin{array}{c}4.67 \\
\pm 0.29\end{array}$ & $\begin{array}{c}5.17 \\
\pm 0.29\end{array}$ & $\begin{array}{c}5.17 \\
\pm 0.29\end{array}$ \\
\hline 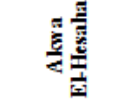 & $\begin{array}{c}19.00 \\
\pm 1.00\end{array}$ & $\begin{array}{c}5.83 \\
\pm 0.29\end{array}$ & $\begin{array}{c}5.77 \\
\pm 0.25\end{array}$ & $\begin{array}{r}4.33 \\
\pm 1.15\end{array}$ & $\begin{array}{r}13.33 \\
\pm 3.21\end{array}$ & $\begin{array}{c}12.16 \\
\pm 0.84\end{array}$ & $\begin{array}{r}73.00 \\
\pm 5.57\end{array}$ & $\begin{array}{l}102.33 \\
\pm 7.28\end{array}$ & $\begin{array}{r}120.00 \\
\pm 17.32\end{array}$ & $\begin{array}{c}63.33 \\
\pm 5.77\end{array}$ & $\begin{array}{r}153.33 \\
\pm 15.28\end{array}$ & $\begin{array}{r}453.33 \\
\pm 35.12\end{array}$ & $\begin{array}{c}5.00 \\
\pm 1.00\end{array}$ & $\begin{array}{c}4.63 \\
\pm 0.55\end{array}$ & $\begin{array}{c}5.00 \\
\pm 0.92\end{array}$ & $\begin{array}{c}\mathbf{5 . 3 0} \\
\pm 0.26\end{array}$ \\
\hline
\end{tabular}

Iron:

Iron is the most abundant trace metals and serves more biological roles than other metals. Iron occurs in two main oxidation forms; the first is ferric $\left(\mathrm{Fe}^{+3}\right)$ oxidized and it is insoluble compound and the second is ferrous $\left(\mathrm{Fe}^{+2}\right)$ reduced and soluble in aqueous media. Therefore, iron precipitate in alkaline and oxidized conditions (El-Enani, 2004).

The present study appeared that, iron concentration in the water was ranged between $33.33 \pm 5.77 \mu \mathrm{g} / \mathrm{L}$ at Kasr Nasr El-Din village during autumn and $1156.67 \pm$ $77.67 \mu \mathrm{g} / \mathrm{L}$ at Kafr El-Zayat City during spring (Table 3). This wide variation may be attributed to the direct precipitation of iron and clarity of water at Kafr El-Zayat City with high probability of industrial wastes. The present results are matching with Daifullah et al. (2003) and Osman et al. (2012) and disagree with Khallaf et al. (2014) who recorded the highest value of iron during autumn and the lowest during summer.

Zinc:

Zinc is an essential metal to all forms of life and a large number of diseases and congenital disorders had been trading to zinc deficiency. Also, it is widely used as skin ointment in the form of zinc oxide (Sader, 1991).

The results (Table 3 ) revealed that, zinc concentration in the water was ranged between $4.33 \pm 0.58 \mu \mathrm{g} / \mathrm{L}$ at Kalleeb Ebiar village during summer and $21.00 \pm 6.24$ $\mu \mathrm{g} / \mathrm{L}$ at Hesset Abar village during the same season. The disturbance in zinc concentration can be attributed to different pollution levels at the studied sites during summer. Such findings were obtained by Abdel-Hamid et al. (2013); however, Daifullah et al. (2003) and Abdel-Satar (2005) did not agree with the present results by recording the lowest concentration of zinc during winter.

The statistical analysis was performed using analysis of variance (ANOVA, at $\mathrm{p}<0.05$ ) on data represent the measured values of heavy metals during the different 
seasons. One way analysis proved that, there are highly significant differences between seasons and metals on the values of heavy metals. However, two ways of ANOVA provided highly significant differences between organs and metals (Table 4).

Table 4: Analysis of variance (ANOVA) performed on the values of environmental factors and heavy metals in the water of El-Bagoria Canal, during the study period.

\begin{tabular}{|c|c|c|c|c|c|}
\hline Sources of variance & \multicolumn{2}{|c|}{ Environmental factors } & \multirow{2}{*}{$\begin{array}{l}\text { Sources of } \\
\text { variance }\end{array}$} & \multicolumn{2}{|c|}{ Heavy metals } \\
\cline { 6 - 7 } & D. F. & F-value & D. F. & F-value \\
\hline Total & 107 & & Total & 48 & \\
\hline Seasons & 3 & $916.03 * *$ & Seasons & 3 & $6.02 * *$ \\
\hline Parameters & 8 & $144044.55 * *$ & Metals & 3 & $18.59 * *$ \\
\hline $\begin{array}{c}\text { Seasons } * \\
\text { Parameters. }\end{array}$ & 24 & $287.69 * *$ & $\begin{array}{c}\text { Seasons } * \\
\text { Metals }\end{array}$ & 9 & $4.07 * *$ \\
\hline Error & 72 & & Error & 33 & \\
\hline
\end{tabular}

Note: $* *=$ highly significant at $\mathrm{p}<0.01$.

\section{Heavy metals in the different organs of $O$. nilotica:}

Fish are often the top of aquatic food chain and may concentrate large amount of some metals such as lead, cadmium, copper, zinc, mercury and iron. So, it can be considered as one of the most significant indicators in freshwater systems for the estimation of pollution level. These metals accumulate differently in fish organs; kidney, brain, muscles, gills, gonads and liver (El-Enani, 2004; Turkmen \& Ciminli, 2007and Ghanem et al., 2015).

\section{Copper concentration:}

To protect fish, the maximum admissible copper concentration in water is within the range of 1 to $10 \mu \mathrm{g} / \mathrm{L}$ depending on the fish species and physico-chemical state of the water (Svobodova et al., 1993). The permissible level of copper in the fish tissue is $20 \mu \mathrm{g} / \mathrm{g}$, (WHO, 1999).

The present data revealed that, copper in the different organs of O. niloticus inhabited El-Bagouria Canal was decreased from $53.41 \pm 20.55 \mu \mathrm{g} / \mathrm{g}$ wet wt. during spring in the liver to $0.6 \pm 0.28 \mu \mathrm{g} / \mathrm{g}$ wet wt. in the muscles during the same season (Fig. 2). These observations were agree with that obtained by Salem et al. (2014) and differed with Demirak et al. (2006) who reported that, copper concentration was peaked in the muscles and declined in the gills. These findings were nearly agreed with Fallah et al. (2011) and disagreed with Edward et al. (2013) who found the highest copper concentration in the gills and the lower one in the muscles.

Accumulations of copper in the different organs of $O$. niloticus showed visible variations with the highest concentration of copper in the liver. However, muscles and gonads were tended to accumulate less level of copper. Fish absorb copper from its feeding diets, sediments and surrounding contaminant waters that, probably received large amounts of industrial, domestic effluents resulting to copper accumulation in different organs of the fish. The higher accumulation in the liver may alter the levels of various biochemical parameters thereby affecting the function of its detoxification and biotransformation of foreign compounds. The differences in the level of heavy metals accumulated by the studied species could be attributed to the differences in their metabolic rates, feeding habits, age, sex and fish species in accordance with Nanda (2014). 




Fig. 2: Seasonal changes of heavy metals in the different organs of O. niloticus inhabiting El-Bagouria Canal, Kafr El-Zayat region, during the period of study.

\section{Manganese concentration:}

Manganese is an essential trace element for micro-organisms, plants and animals although that, it is sometimes exhibits toxicity (Burger and Gochfeld, 1995). The maximum permissible limit of manganese in the fish tissues according to $\mathrm{WHO} / \mathrm{FAO}$ is $5.5 \mathrm{mg} / \mathrm{kg}$ (Tiimub and Afua, 2013).

Results showed that, manganese concentration in the different organs of $O$. niloticus inhabited El-Bagouria Canal exhibited its highest peak during spring in the liver and the lower one during autumn in the kidney; being $13.5 \pm 3.0 \mu \mathrm{g} / \mathrm{g}$ wet wt. in the first and $0.5 \pm 0.09 \mu \mathrm{g} / \mathrm{g}$ wet wt. in the second (Fig. 2). These findings are agreed with Monferrán et al. (2015) and disagreed with Meche et al. (2010) who obtained the highest level of manganese during autumn and the lowest during summer. The concentrations of manganese in the different organs of $O$. niloticus showed remarkable variations with highest peak in the gonads and liver. This observation also agree with Al-Yousuf et al. (2000), who attributed that due to the greater tendency of the elements to react with the oxygen carboxylate, aminogroup, nitrogen and/or sulphur of the mercapto group in the metallothionein protein, which concentrate in the liver. The higher level of manganese in the liver and gonads of the fishes could be due to the fact that, manganese is naturally abundant in the soils, which is the main source of metals in the surrounding water of the fish samples as it is generally accepted that heavy metal uptake mainly from food, sediment and water that might be polluted with industrial and agricultural effluents discharged directly into the canals of study areas.

\section{Iron concentrations:}

Iron is essential to most life forms and to normal human physiology. According to WHO/FAO the maximum permissible limit of iron in the fish tissues is $43 \mathrm{mg} / \mathrm{kg}$ (Tiimub and Afua, 2013).

The present data (Fig. 2) declared that, the maximal iron value in the soft tissues of $O$. niloticus was measured during winter in the liver $(104.18 \pm 27.24 \mu \mathrm{g} / \mathrm{g}$ wet wt.) and the minimum $(4.66 \pm 2.46 \mu \mathrm{g} / \mathrm{g}$ wet wt.) occurred during summer in the muscles. Data indicated that, the highest concentrations of iron were accumulated in the liver followed by kidney. These results may be due to the influence of surrounding ecosystem or may be attributed to the abundance of iron metals in the water and sediment in addition to the amount of pollutants in the aquatic environment. Fish liver 
is directly proportional to the degree of pollution by heavy metals, as liver is a target organ of accumulation for metals and highly active in the uptake and storage of heavy metals, while muscle is not an active tissue in accumulating heavy metals. The elevation of iron in the metabolic organs confirm that, the surrounding environment is contaminated with industrial wastes, sewage and agricultural effluents that discharged into canal stream without any treatments to find their way inside the fish organs through their food. These observations are similar to that obtained by Yehia and Sebaee (2012) and differed with Eneji et al. (2011) who recorded the maximum value in the gills and the minimum one in the intestine.

\section{Zinc concentration:}

Zinc is one of the most abundant essential trace elements in the human body. It is a constituent of all cells and several enzymes depend upon it as a co-factor (Forstner and Wittmann, 1983). According to the declaration of trace heavy metals in fisheries and microbiological control, the permissible tolerance limits of $\mathrm{Zn}$ in fresh fish are $50 \mu \mathrm{g} / \mathrm{g}$ wet wt. (Taş et al., 2011).

Results (Fig. 2) revealed that, the concentration of zinc in the different organs of $O$. niloticus attained its maximum value during winter in the liver and the minimum one during summer in the muscles $(25.25 \pm 3.93 \mu \mathrm{g} / \mathrm{g}$ wet wt. in the former and 0.58 $\pm 0.54 \mu \mathrm{g} / \mathrm{g}$ wet wt. in the latter). These findings are in agreement with Osman (2012) and in contrast with Adeyeye et al. (1996) who recorded the higher level of zinc in the muscles of Tilapia sp. The previous data declared that, the highest concentrations of zinc were accumulated mainly in the gonads followed by liver. This elevation of zinc in the gonads of fish may be attributed to decomposition of organic matter and agricultural wastes that contain residual zinc and/or may be also associated to reproductive processes. Since gonads are likely to have high zinc concentration due to their participation in cellular division and growth processes.

Data in Table (5) showed the statistical analysis using analysis of variance (ANOVA, at $p<0.05$ ) based on data represent the measured values of heavy metals in the different organs of $O$. niloticus during the different seasons. One way analysis proved that, there were highly significant differences between the metals and between the different seasons also between different organs.

Table 5: Analysis of variance (ANOVA) performed on the values of heavy metals and biochemical parameters in the different organs of Oreochromis niloticus, during the study period.

\begin{tabular}{|c|c|c|c|c|c|}
\hline \multirow{2}{*}{ Sources of variance } & \multicolumn{2}{|c|}{ Heavy metals } & \multirow{2}{*}{ Sources of variance } & \multicolumn{2}{|c|}{ Biochemical parameters } \\
\hline & D. F. & F-value & & D. F. & F-value \\
\hline Total & 63 & & Total & 79 & \\
\hline Seasons & 3 & $4.81 * *$ & Seasons & 3 & $3.98 *$ \\
\hline Organs & 3 & $33.71 * *$ & Organs & 3 & $3.59 *$ \\
\hline Metals & 3 & $71.93 * *$ & Parameters & 4 & $11.24 * *$ \\
\hline Seasons * Organs & 9 & 1.75 n.s. & Seasons * Organs & 9 & 0.88 n.s. \\
\hline Seasons * Metals & 9 & 1.19 n.s. & Seasons*Parameters & 12 & 1.96 n.s. \\
\hline Organs * Metals & 9 & $16.86^{* *}$ & Organs*Parameters & 12 & $4.52 * *$ \\
\hline Error & 27 & & Error & 36 & \\
\hline
\end{tabular}

On the other hand, two ways of ANOVA provided highly significant differences between organs and metals at the same seasons. While, non-significant differences were showed at the interactions between seasons and organs at the same metals and between seasons and metals at the same organs. 


\section{Biochemical analysis in the fishes:}

The toxic effects of heavy metals on the fish have been demonstrated. It is abundantly clear that metals induce an early response in the fish as evidenced by alterations both at structural and functional levels of different organs including enzymatic and genetic effects, thereby affecting the innate immune system of exposed fish and/or increasing susceptibility to multiple types of disease (Authman et al., 2015).

\section{Total proteins:}

Total proteins play an important role in the metabolism and regulation of water balance. Blood protein and enzyme levels in rainbow trout are affected by metals (Dethloff et al., 1999).

Results showed that, the maximum value of total proteins in the different organs of O. niloticus was detected in the kidney during spring $(108.8 \pm 20.68 \mathrm{mg} / \mathrm{g}$ wet wt.) and the minimum $(44.8 \pm 4.54 \mathrm{mg} / \mathrm{g}$ wet wt.) was recorded during summer in the liver (Fig. 3). The present results confirmed that, there was clear depletion in the content of total proteins among different organs of studied fishes. This depletion may be explained on the basis of energy production during the pollutant toxicity through metabolic utilization of the ketoacids to gluconeogenesis pathway for the synthesis of glucose. These observations are similar to those obtained by Sobha et al. (2007) and El-Nabarawy (2014), who attributed low protein to other several pathological processes including impairment in protein synthesis machinery, renal damage and elimination in hepatic blood flow or plasma dissolution. Unsimilar findings were notably by Zaghloul (2000), who reported increasing in total proteins in soft tissues of the fishes exposed to heavy metals. This increasing in protein content may be also a mechanism of maturation of gonad and storage of reserves to meet spawning requirements (Jan et al., 2012).



Fig. 3: Seasonal changes of metabolic parameters in the different organs of $O$. niloticus inhabiting El-Bagouria Canal, Kafr El-Zayat region, during the period of study.

\section{Total lipids:}

Lipids are an important component in human diets, both as energy and fatty acids sources. Fish like other animals, have the ability to accumulate lipids in their 
body. Fat content is influenced by species, geographical region, age and diet (Sargent et al., 2002).

The present study declared that, total lipid in the target organs of O. niloticus collected from El-Bagouria Canal was increased gradually from $85.2 \pm 5.17 \mathrm{mg} / \mathrm{g}$ wet wt. in the gonads during summer to $205.8 \pm 21.0 \mathrm{mg} / \mathrm{g}$ wet wt. in the same organ during winter (Fig. 3). According to the present data, the low concentration of lipids in different organs of the fish species especially the muscles could be attributed to poor storage mechanism and the use of fat reserves during spawning activity or imposition of high energy demands to counter the toxic stress beside many other factors that affect the lipids content of fish as seasonal effect, different provisioning origins and a reproduction period. The present results are nearly similar to those obtained by Sobha et al. (2007) and Mohanty et al. (2013) and disagree with Javed and Usmani (2015) who reported the increasing in lipids content in the internal tissues of fish exposed to heavy metals.

\section{Total carbohydrates:}

Carbohydrates serve as the instant energy source during stress, so during acute condition blood glucose level increases due to glycogenolysis but reduction can be correlated to utilization of stored glycogen to meet the energy demand or chronic exposure. In the liver, glycogen mobilizes to glucose whereas in the muscles glycogen /glucose served as readily available source of energy, thus hypoglycemia was observed (Javed and Usmani, 2015). Stress response in the fish is generally characterized by the increasing in adrenalin causing mobilization of liver glycogen into blood glucose (Swallow \& Flemming, 1970 and Wepener, 1990).

Data revealed that, the content of total carbohydrates in the organs of $O$. niloticus collected was increased gradually from $1.25 \pm 0.16 \mathrm{mg} / \mathrm{g}$ wet wt. in the gonads during summer to $24.38 \pm 2.33 \mathrm{mg} / \mathrm{g}$ wet wt. in the liver during autumn (Fig. 3 ). Results showed remarkable elevation of total carbohydrates content in the liver tissues and decreasing in the fish muscles. The obtained results explain the fact that, heavy metals increase the glucose content in the blood, because of intensive glycogenolysis and the synthesis of glucose from extra-hepatic tissue proteins and aminoacids (Almeida et al., 2001). While, the decreasing in glycogen content in the muscles may be due to the inhibition of hormones which contribute to glycogen synthesis. These results are in agreement with Sobha et al. (2007) and Maharajan et al. (2012). While, different observations were recorded by Kavidha \& Muthulingam (2014), who observed a remarkable decline in the carbohydrates content due to its rapid utilization to meet the reduced energetic efficiency at long exposure to heavy metals.

\section{ASAT (Aspartate aminotransferase) activity:}

Many studies consider that, the activity of alanine aminotransferase and aspartate aminotransferase is a sign for liver disease such as liver fibrosis, which may induce by several reasons such as chemicals, virus... etc. (Lee and Farrell, 1997).

ASAT activity in the target tissues of $O$. niloticus inhabited El-Bagouria Canal (Fig. 4) exhibited its maximum level in the muscles during winter and the lower one in the kidney during summer; being $3044.8 \pm 641.78 \mathrm{U} / \mathrm{mg}$ wet wt. in the first and $16.8 \pm 8.8 \mathrm{U} / \mathrm{mg}$ wet wt. in the latter.

The present data of ASAT illustrated that, the discharge of different effluents into the studied canal elevated heavy metals levels and reduced the activity of vital organs of O. niloticus; these heavy metals caused different degrees of injuries in the fish tissues and elevated ASAT activity. Also, results suggested that, the pollutants of 
Nile water may be toxic to fish's cells, such toxic effects could be lipolytic in nature as a result the cell organelles releasing the enzymes into the blood.

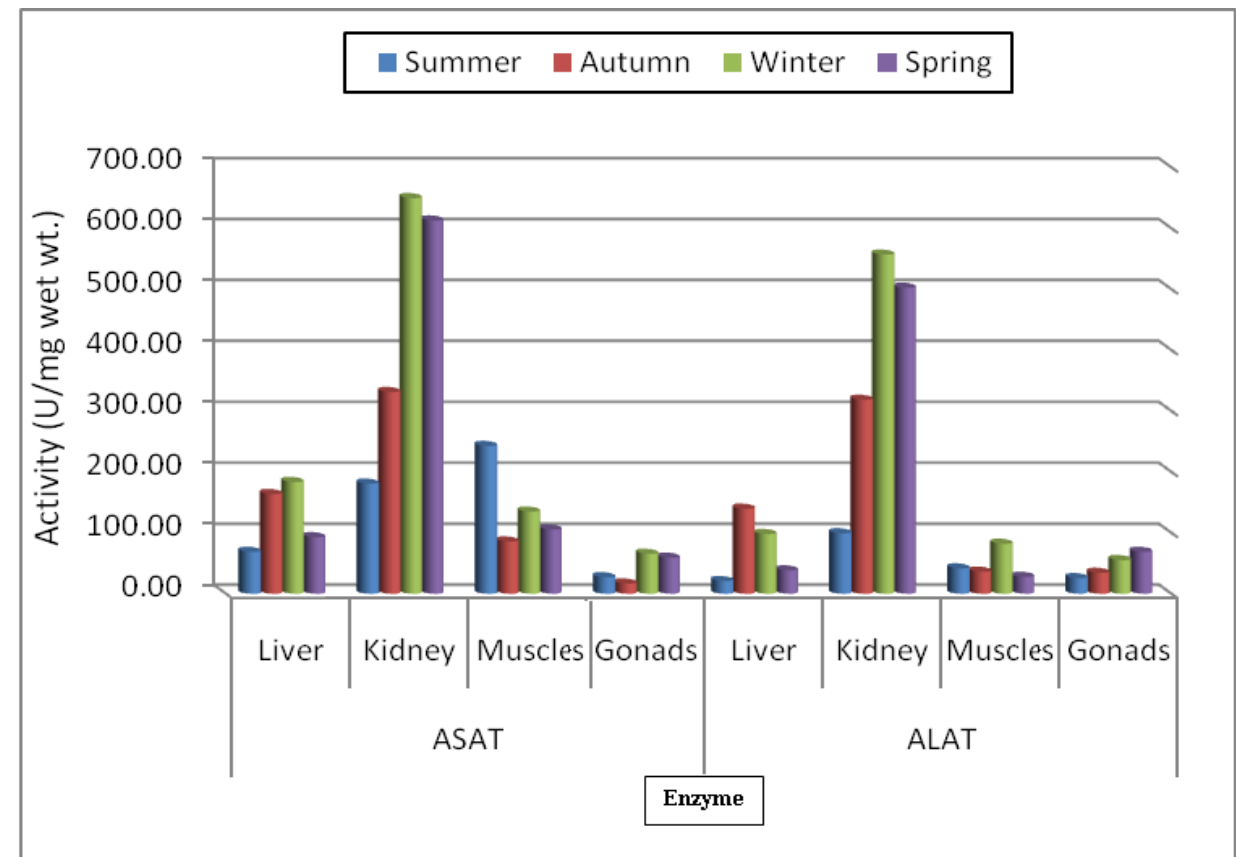

Fig. 4: Seasonal changes of enzymes activities in the different organs of O. niloticus inhabiting ElBagouria Canal, Kafr El-Zayat region, during the period of study

Hence, the increased ASAT activity in the present investigation may be a result of liver cell damage. The obtained results are relatively compatible with those obtained by El-Seify et al. (2011) and Abumourad et al. (2013) while the incompatible observations were observed by Mohamed \& Gad (2008) who recorded depletion in the activity of ASAT as a result of heavy metals stress.

ALAT (alanine aminotransferase) activity:

Alanine aminotransferase (ALAT) couple the protein, carbohydrate and fat metabolism and tricarboxylic acid cycle under altered physiological, pathological and induced environmental conditions (Murugesan et al., 1999).

The highest activity of alanine aminotransferase in the soft tissues of $O$. niloticus was observed in the kidney during winter $(556.8 \pm 146.28 \mathrm{U} / \mathrm{mg}$ wet wt.) and the lowest one $(20.8 \pm 1.27 \mathrm{U} / \mathrm{mg}$ wet wt.) was determined in the liver during summer (Fig. 4). Data suggested that, pollutants and different effluents that discharged into the canal elevated ALAT activity in the internal organs of $O$. niloticus. This may be attributed to the toxicity of heavy metals leading to production of mitochondrial enzymes which were subsequently released into the blood as a result of tissues damage. These findings are nearly agree with Thyagarajan et al. (2015) and disagree with Hedayati \& Safahieh (2011), who recorded falling in ALAT activity due to heavy metals stress.

Data in Table (5) show the statistical analysis using analysis of variance (ANOVA, at $\mathrm{p}<0.05$ ) based on data represent the measured values of biochemical parameters in the different organs of $O$. niloticus during the different seasons. One way analysis proved that, there were highly significant differences between the parameters. Meanwhile, there were significant differences between the different seasons and between target organs. Moreover, two ways of ANOVA provided highly significant differences between organs and parameters at the same seasons. While, non-significant 
differences were showed at the interactions between seasons and organs at the same parameters and between seasons and parameters at the same organs.

\section{CONCLUSION AND RECOMMENDATIONS}

The levels of accumulation of trace metals in the various organs of fish reflect to good extent the degree of aquatic environmental pollution by such metals. Therefore, fish can be considered as a good indicator for the pollution of aquatic environment.

The accumulation of heavy metals caused different degree of injuries in the livers, kidney of investigated fish species.

It is must to protect River Nile from pollution to reduce environmental risks and this study may provide preliminary database for future research on trace metals of the study area.

A recommendation can be made that it is advisable for public health that human must be use only muscles of fish for food and that the internal organs must not be used as fish meal for other purposes.

Making a research lab with new scientific techniques to monitor any defect in the physiology of fish, this in turn affects human health.

\section{REFERENCES}

Abdel-Aziz, G. S. (2005): Study on the water quality of the River Nile with relation to the environmental condition at El-Kanater El-Khyria region. M. Sc. Thesis, Fac. Sci (Girls) Al-Azher Univ. Cairo, Egypt.

Abdel-Hamid, A.M.; Gomaa, A. H. and El-Sayed, H.G.M. (2013): Studies on some heavy metals in the River Nile water and fish at Helwan area, Egypt. Egypt. J. Aquat. Biol. and Fish., 17(2): 105- 126.

Abdel-Satar, A.M. (2005): Water quality assessment of River Nile from Idfo to Cairo. Egypt J. Aquatic Res., 31(2): 200 - 223.

Abdo, M. H. (2004): Environmental studies on the River Nile at Damietta branch region, Egypt. J. Egypt. Acad. Soc. Environ. Develop., (D- Environmental Studies), 5 (2): $85-104$.

Abumourad, I.M.K. ; Authman, M.M.N. and Abbas, W.T. (2013): Heavy Metal Pollution and Metallothionein Expression: A Survey on Egyptian Tilapia Farms. J. Appl. Sci. Res., 9(1): 612-619.

Adeyeye, E.I.; Akinyugha, N.I.; Fesobi, M.E. and Tenabe, V.O. (1996): Determination of some metals in Clarias gariepinus ( Cuvier and Vallenciennes), Cyprinus carpio ( L.) and Oreochromis niloticus (L.) fishes in a polyculture fresh water pond and their environments. J. Agric., 147: 205-214.

Ahmed, N.A.M. (2012): Biochemical studies on pollution of the River Nile at different stations of Delta Barrage (Egypt). Ph.D. Thesis, Fac. Agri., Benha Univ., Egypt.

Alawy, A.E.; El-Tras, W.F.; Khater, D. F. and El- Raiy, H.A. (2015): Impact of industrial wastewater on water and fish quality of Nile River in Kafr El-Zayat, Egypt. Benha Vet. Med. J. 28(1):78-87.

Almeida, J.E.; Novelli, M. Dal-Pai S. and Junior, R. (2001): Environmental cadmium exposure and metabolic responses of the Nile tilapia Oreochromis niloticus. Environ. Pollut., 114:169-175.

Al-Obaidy, A.M.J.; Talib. A. H. and Zaki, S. R., (2015): Application of water pollution index for assessment of Tigris River ecosystem. Int. J. Adv. Res., 3 (2): 219-223. 
Al-Yousuf, M.H.; El-Shahawi, M.S. and Al-Ghais, S.M., (2000): Trace metals in liver, skin and muscle of Lethrinus lentjan fish species in relation to body length and sex. Sci. Total Environ., 256: 87-94.

APHA, AWWA and WEF. Eugene W. Rice; Andrew D. Eaton and Lenore S. Clesceri. (2005): American Public Health Association, American Water Work Association, Water Environment Federation. Standard Methods For The Examination Of Water And Wastewater. $21^{\text {st }}$ edition, 800, I St. NW., Washington DC 20001-3710.

APHA, AWWA and WEF. Eugene W. Rice; Andrew D. Eaton; Rodger B. Baird and Lenore S. Clesceri. (2012): American public health association, American Water Works Association and Water Environment Federation, Standard Methods For The Examination Of Water and Wastewater, $22^{\text {nd }}$ edition, NW, Washington.

Ashry, M. A.; Mahmoud, S. A. and Abd El-Rahman, A. A. S. (2013): Histopathological studies on the hematopoietic organs of Clarias gariepinus in relation to water quality criteria at different localities in the River Nile, Nature and Sci., 11(8):78-88.

Authman, M.M.N.; Zaki, M.S.; Khallaf, E.A. and Abbas, H.H. (2015): Use of fish as bioindicator of the effects of heavy metals pollution. J. Aquac. Res. Develop., 6(4):113.

Bailey, N. T. J. (1981): Statistical methods in biology. $2^{\text {nd }}$ Ed. (Biological Science Texts): 216pp.

Bujar, H. D.; Bacaj, M.; Ismaili, I.; Jusufi, S.; Dehari, SH.; Abduli, Sh. and Dehari, D. (2008): The physical, physical-chemical and chemical parameters determination of water Shkumbin (Pena) River. Conference, $10^{\text {th }}$ international symposium on water management and hydraulic engineering, Šibenik, Croatia. Vol. 10.

Burger, J. and Gochfeld, M. (1995): Growth and behavioral effects of early postnatal chromium and manganese exposure in herring gull (Larus argentatus) chicks. J. Pharmacol. Biochem. Behav., 50: 607-612.

Burtis, C. A. and Ashwood, E. R. (1999): Specimen collection and processing: Sources of biological variation", Tietz Textbook of Clinical Chemistry, 3rd Edition, W. B. Saunders, Philadelphia PA.

Chandra, R.; Singh, S. and Raj, A., (2006): Seasonal bacteriological analysis of Gola River water contaminated with pulp paper mill waste in Uttaranchal, India. Environ. Monit. Assess., 118: 393-406.

Ciesielski, T.; Pastukhov, M.V.; Szefer, P. and Jensen, B.M. (2010): Bioaccumulation of mercury in the pelagic food chain of Lake Baikal. Chemosphere, 78: 1378-1384.

Daboor, S. M. (2006): Studied on bacterial flora and its role in the cleanup of hazardous pollutants in the River Nile, Ph.D. Thesis, Fac. Sci. Zagazig Univ., Egypt.

Daifullah, A.A.M.; Elewa, A.A.; Shehata, M.B. and Abdo, M.H. (2003): Evaluation of some heavy metals in water, sediment and fish samples from the Nile River (Kafr El-Zayat city), Egypt. Afric. J. Environ. Asse. Manag. 6: 6-31.

Das, P.C.; Ayappan, A.J.; Jena, J.K. and Das, B.K. (2004): Acute toxicité of ammonia and sub lethal effects on marigal (Cirrhinus mrigala) Hamilton, Aquate. Res., 35: 134-143.

Demirak, A.; Yilmaz, F; Tuna, A. L. and Ozdemir, N., (2006): Heavy metals in water, sediment and tissues of Leuciscus cephalus from a stream in southwestern Turkey. Chemosphere, 63: 1451-1458.

Dethloff, G.M.; Schlenk, D.; Khan, S. and Bailey, H.C. (1999): The effects of copper on blood and biochemical parameters of rainbow trout (Oncorhynchus mykiss). Arch. Environ. Contam. Toxicol., 36:415-423.

Eddy, F.B. (2006): Cardiac function in juvenile salmon (Salmo Salar L.) in response to lipopolyscharide (LPS) and inhibitor of Inducible Nitric Oxide Synthase (IONS). Fish Physiol. Biochem., 31: 339-346. 
Edward, J.B.; Idowu, E.O.; Oso, J.A. and Ibidapo, O.R., (2013): Determination of heavy metal concentration in fish samples, sediment and water from odo-ayo River in Ado-Ekiti, Ekiti-State, Nigeria. Int. J. Environ. Monit. Anal., 1(1):27-33.

El-Bouraie, M.M.; Eman, A. M.; Gehad, G.M. and Yehia, M.M. (2011): Water quality of rosetta branch in Nile delta. Egypt, Helsinki, Suo., 62(1): 32 - 37.

El-Enani, H. R., (2004): Ecological and biological studies on Lake El-Manzala with special reference to their water quality and sediment productivity. M. Sc. Thesis, Fac. Sci., Al Azhar Univ., 358 pp.

El-Gammal, T. (2009): Rehabilitation of El-Bagoriya and Tanta Navigation canals, water management research institute, Preliminary study about El-Bagoriya canal, Irrigation Sector.

El-Nabarawy, S.K. (2014): A comparative study on lipid and protein composition of Oreochromis niloticus muscles from five different localities in Egypt. Egypt. J. Aquat. Biol. \& Fish., 18 (2): 63- 73.

El-Otify, A. M. and Iskaros I. A. (2015): water quality and potamoplankton evaluation of the Nile River in Upper Egypt; Acta Limnol. Bras. 27 (2): 171-190.

El-Seify, M.A.; Zaki, M. S.; Abdel Razek, Y.D.; Hossam, H. A.; Osman, K.A. and Attia, A.A., (2011): Study on clinopathological and biochemical changes in some freshwater fishes infected with external parasites and subjected to heavy metals pollution in Egypt. J. Life. Sci., 8(3): 401-405.

Emara, M.M.; Farag, R.S.; Sorour, S. and Sabry, Z.W. (2012): assessment the efficiency of conventional water treatment and direct filtration on drinking water quality based on seasonal change in physico-chemical characteristics of raw Nile water. J. Appl. Sci. Res., 8(1): 57-64.

Eneji, I.S.; Ato, R.Sh. and Annune, P.A. (2011): Bioaccumulation of Heavy Metals in Fish (Tilapia zilli and Clarias gariepinus) Organs from River Benue, North-Central Nigeria, Pak. J. Anal. Environ. Chem., 12(1-2): 25 - 31.

Entz, B.A.G. (1973): The morphology of Lake Nasser, Lake Nasser development center, RPA, UNDPISF, FAO Aswan, Egypt, pp. 1- 18.

Ezzat, S.M.; Hesham, M.; Mahdy, M.A.; Abo-State, E.; Abdel-Shakour, H. and ElBahnasawy, M.A. (2012): Water quality assessment of river Nile at Rosetta branch: Impact of drains discharge. Middle-East J. Sci. Res., 12(4): 413-423.

Fallah, A.A; Siavash, Saei-Dehkordi, S.; Nematollahi, A. and Jafari, T. (2011): Comparative study of heavy metal and trace element accumulation in edible tissues of farmed and wild rainbow trout (Oncorhynchus mykiss) using ICP-OES technique. Microchem. J., 98: 275-279.

Forstner, U. and Wittmann, G. T. W. (1983): Metal pollution in the aquatic environment. Springer-Verlag, Berlin., pp. 30-61.

Frolund, B.; Palmgren, R.; Keiding, K. and Nielsen, P.H. (1996): Extraction of extracellular polymers from activated sludge using a cation exchange resin. Water Res. 30(8): 1749-1758.

Ghallab, M. H. M. (2000): Some physical and chemical changes on River Nile Down Stream of Delta Barrage at El-Rahawy Drain. M. Sc. Thesis Fac. Sci. Ain Shams Univ. Cairo, Egypt.

Ghanem, M.H.M. (2011): Seasonal variations of total proteins, lipids and carbohydrates in cultivated, brackish and salt water fishes with special references to their nutrient values. .Ph. D. Thesis, faculty of Science, Al-Azhar Univ., Cairo., 395pp.

Ghanem, M.H.; Shehata, S.M.; Abu-Zaid, M.M.; Abdel-Halim, A.M. and Abbas, M.M. (2015): Accumulation of some heavy metals in the muscles of Diplodus sargus, inhabiting El-Mex Bay (Alexandria, Mediterranean Sea) with special references to its physiological responses. Int. J. Environ. Sci. Engineer., 6: 1-13. 
Ghannam, H.E.; Talab, A.S.; Jahin, H.S. and Gaber, S.E. (2014): Seasonal variations in physicochemical parameters and heavy metals in water of El-Bahr El-Pharaony drain, El-Menoufia Governorate, Egypt. Res. J. Environ. Earth Sci., 6: 174-181.

Goher, M.E. (2002): Studies on the precipitation and dissolution of some chemical element in Lake Qarun, Ph. D. Thesis. Fac. Al-Azhar Univ., Egypt.

Grey, D. and Sadoff, W.C (2007): water security for growth and development, Water Policy. 9:545-571.

Haiyan, W. and Stuanes, A. O. (2003): Heavy metal pollution in air-water-soil-plant system of Zhuzhou City, Hunan Province, China. Water Air and Soil Pollut., 147: 79-107.

Hassanein A. M.; Abdel-Rahim, K. A. A.; Younis, S.M.; Ismael, M.; Abdel- Azeiz H. A., (2013): Physicochemical and microbiological studies of River Nile water in Sohag governorate. J. Environ. Stud. 10: 47-61

Has-Schön, E.; Bogut, I. and Strelec, I. (2006): Heavy metal profile in five fish species included in human diet, domiciled in the end flow of river Neretva [Croatia]. Arch. Environ. Contam. Toxicol., 50:545-551.

Hedayati, Aa. and Safahieh, A. (2011): Serum hormone and biochemical activity as biomarkers of mercury toxicity in the yellowfin seabream Acanthopagrus latus. J. Toxicol. Ind. Health, 1: 1-14.

I.F.C.C. [International Federation of Clinical Chemistry] (1986): Expert panel on enzymes part 3. J. Clin. Chem. Clin. Biochem., 24:481-495.

Ibrahim, A.T. and Omar, H.M. (2013): Seasonal variation of heavy metals accumulation in muscles of the African Catfish Clarias gariepinus and in River Nile water and sediments at Assiut Governorate, Egypt. J. Bio. Earth Sci., 3(2):B236-248.

Jan, U.; Shah, M.; Manzoor, T. and Ganie, S. A. (2012): Variations of protein content in the muscle of fish Schizothorax niger. Am-Euras. J. Sci. Res., 7 (1): 01-04.

Javed, M. and Usmani, N. (2015): Stress response of biomolecules (carbohydrate, protein and lipid profiles) in fish Channa punctatus inhabiting river polluted by thermal Power Plant effluent. Saudi. J. Biol. Sci., 22: 237-242.

Kadry, S. M.; Tayel, S. I.; Afify, M. F.H. and El-Sayed, R. A. (2015): Ecohistopathological studies on Oreochromis niloticus fish living in Damietta Branch in Egypt. World J. Pharm. Sci., 3(5): 815-825.

Katz, H. and Navone, R. (1964): Method for simultaneous determination of calcium and magnesium. J. Am. Water Works Assoc. 56:121

Kavidha, K. and Muthulingam, M. (2014): Lead acetate induced glycogen level alterations in gill and kidney tissues of freshwater fish Cyprinus carpio (linn.). Int. J. Modn. Res. Revs., 2 (11): 517-521.

Khallaf, E.A.; Galal, M.; El-Sbbagh, S. and Nabet, N.M. (2014): A study of the physicochemical characteristics of raw, filtered, and treated water at a water treatment plant in Shebin El-Kom, Egypt. Egy. J. Aqu. Biol. and Fish.,18(1): 115-125.

Lee, A.U. and Farrell, G.C. (1997): Drug-induced liver disease. Curr.Opin. Gastroen. 13:199-205.

Mahananda, M.R. (2010): Physico-chemical analysis of surface water and ground water of Bargarh District, Orissa, India. Int. J. of Res. and Rev. in Appl. Sci., 2 (3): 284295.

Maharajan, A.; Rajalakshmi, S. and Vijayakumaran, M. (2012): Effect of copper in protein, carbohydrate and lipid contents of the juvenile lobster, Panulirus homarus homarus. Sri Lanka J. Aquat. Sci., 17: 19-34.

Meche, A.; Martins, M.C.; Lofrano, B.E.; Hardaway, C.J.; Merchant, M. and Verdade, L. (2010): Determination of heavy metals by inductively coupled plasma-optical emission spectrometry in fish from the Piracicaba River in Southern Brazil. Microchem. J., 94: 171-174. 
Mohamed, F.A. and Gad, N. S. (2008): Environmental pollution induced biochemical changes in tissues of Tilapia zillii, Solea vulgaris and Mugil capito from Lake Qarun, Egypt .Glob. Vet. 2(6): 327-336.

Mohanty, B.P.; Mahananda, M.R. and Pradhan, S. (2013): Cadmium induced toxicity and antioxidant activities in Labeo Rohita (Hamilton). Environ. Ecol. Res., 1(2): 41-47.

Monferrán, M. V.; Garnero, P.; Bistoni, M.D.A.; Anbar, A.A.; Gordon, G.W. and Wunderlina, D.A. (2015): From water to edible fish. Transfer of metals and metalloids in the San Roque Reservoir (Córdoba, Argentina). Implications associated with fish consumption. J. Ecol. Indic., 63: 48-60.

Moustafa, M.M.; Ali, M.H.H.; Abdel-Satar, A.M.; Mohamed, T.Y. and Madbouly, S.M. (2010): Water quality assessment of Rosetta and Damietta branchs, River Nile, Egypt. African J. Biol. Sci., 6(2): 127-142.

Murugesan, R.; Palaniswamy, T. and Panneer, N. (1999): S.Glutamic oxaloacetic transaminase (GOT) and glutamic pyruvic transaminase (GPT) enzyme activities in different tissues of Sarotherodon mossambicus (Peters) exposed to a carbamate pesticides, carbaryl. Pestic. Sci., 55(12):1217- 1221.

Nanda, P. (2014): Bioaccumulation of heavy metals and physiological response in Anabas testudineus on exposure to paper mill effluent. J. Environ. Anal. Toxicol., 5(1):1-8.

Negm, A.M.; Abdel-Aziz, T.M.; Salem, M.N.; and Yousef, W. (2011): Impact of future discharges on Damietta Branch morphology. $15^{\text {th }}$ Int. Water Tech. Conf., Alexandria, Egypt.

Noor El- Deen, A. E.; Zaki, M. S. and Osman, H. A. (2010): Role of fulvic acid on reduction of cadmium toxicity on Nile Tilapia (Oreochromis niloticus). Report and Opinion. 1(5):52-57.

Osman, A. G. M. (2012): Biomarkers in Nile Tilapia Oreochromis niloticus (Linnaeus, $1758)$ to assess the impacts of River Nile pollution: bioaccumulation, biochemical and tissues biomarkers. J. Environ. Protec., 3: 966-977.

Osman, A.G.M. and Kloas, W. (2010): Water quality and heavy metal monitoring in water, sediments, and tissues of the African catfish (Clarias gariepinus) (Burchell, 1822) from the River Nile, Egypt. J. Environ. Protec., 1: 389-400.

Osman, A.G.M.; Abuel-Fadl, K. Y.; Elbtar, A. M. and Taha, M.A.M, (2012): Seasonal variation of some heavy metals in water, sediment and fish samples collected from the River Nile, Egypt. Environ. Res. J., 6 (5): 321-328.

Otles S. and Cagindi, O. (2010): Health importance of arsenic in drinking water and food. Environ. Geochem. Health., 32 (4):367-371.

Ravindra, K.; Meenakshi, A.; Rani, M. and Kaushik, A., (2003): Seasonal variations in physico-chemical characteristics of River Yamuna in Haryana and its ecological best-designated use. J. Environ. Monit., 5: 419-426.

Roberts, G. and Marsh, T. (1987): The effects of agricultural practices on the nitrate concentration in the surface waters domestic supply sources of Western Europe. In: Water for the future hydrology in perspective, IAHS Publications, 164: 365-380.

Sader, J. P. (1991): Inorganic chemistry and drug design. In Adv. Inorganic Chem., 36 (Ed). A. G. Sykes. Academic press., pp. 1- 44.

Salem, Z. B.; Capellia, N.; Laffray, X.; Elisea, G.; Ayadib, H. and Aleyaa, L., (2014): Seasonal variation of heavy metals in water, sediment and roachtissues in a landfill draining system pond (Etueffont, France). J. Ecol. Eng., 69: 25-37.

Sargent, J.R.; Tocher, D.R. and Bell, J.G. (2002): The lipids, In: Fish Nutrition, 3rd edition, Halver, J.E., Hardy, R.W. (Eds.), Academic Press, San Diego, pp. 181-257.

Siddaramu, D. and Puttaiah, E.T. (2013): Physicochemical characteristics of Balagala Kere and Purali Kere of Shimoga District, Karnataka, India. Int. J. Adv. Res., 1(8): 313-321. 
Sobha, K.; Poornima, A.; Harini, P. and Veeraiah, K. (2007): A study on the biochemical changes in freshwater fish Catla catla exposed to the heavy metal toxicant, cadmium chloride. Kathmandu University J. Sci. Engineer. Technol., 1(4):1-11.

Suruchi, S. and Khanna, P. (2011): Assessment of heavy metal contamination in different vegetables grown in and around urban areas. Research Journal of Environmental Toxicology 5:162-179.

Svobodova, Z.; Lloyd, R.; Machova, J. and Vykusova, B. (1993): Water quality and fish health. (EIFAC). F.A.O., 54: 59 pp.

Swallow, A. and Flemming, P. (1970): The Effect of oxaloacetate, ACTH and cortisol on the liver glycogen levels of Tilapia mossambica. Comp. Biochem. Physiol., 36(1): 93-98.

Taş, Ç. E.; Filipuçi, I.; Türker, D. Ç.; Beyaztaş, S.; Sunlu, U.; Toğulga, M.; Özaydın, O. and Arslan, O. (2011): Heavy metal concentrations in tissues of edible fish (Mullus barbatus L., 1758) from the Çandarli bay, Turkey. Fresen. Environ. Bull., 20 (11): 2834-2839.

Thyagarajan, R.; Keshav, V.; Narendrakumar, G.; Selvam, M.M. and Rameshkumar, V. (2015): Effect of copper sulphate on aspartate aminotransferase (ASAT) and alanine Aminotransferase (ALAT) activity in freshwater fish Ariopsis seemanni. Res. J. Pharmaceut., Biol. \&Chem. Sci., 6 (1): 1219-1224.

Tietz, N.W. (1976): Fundamentals of clinical chemistry, 2nd edition, Saunders, Philadelphia, $876 \mathrm{pp}$.

Tiimub, B. M. and Afua, M.A.D. (2013): Determination of selected heavy metals and iron concentration in two common fish species in Densu River at Weija District in Grater Accra Region of Ghana Am. Int. J. Biol., 1(1): 45-55.

Turkmen, M. and Ciminli, C. (2007): Determination of metals in fish and mussel species Byinductively coupled plasma-atomic emission spectrometry. J. Food Chem., 103: 670-675.

UNEP (1984): Sampling of selected marine organisms and sample preparation for trace metal analysis. Reference Methods for Marine Pollution Studies No. 7, Rev. 2, UNEP, Nairobi.

Venkatesha, K. R.; Somashekar, R. K. and Prakash, K. L. (2013): Spatio-temporal variation of heavy metals in Cauvery River basin. Int. Acad. Ecol. Environ. Sci., 3(1): 59-75.

W. H. O. (1999): Food safety issues associated with products from aquaculture. Report of a Joint World Health Organ. Tech. Rep., 883: 1-55.

Wepener, V. (1990): The effect of heavy metals at changing $\mathrm{pH}$ on the haematology and metabolism of Tilapia sparrmanii (Cichlidal). M.Sc. thesis Rand Africans University, $119 \mathrm{pp}$.

Willard, H. H.; Merritt, L. L. and Dean, J. A. (1974): Instrumental Methods of Analysis, 5th ed. D. Van Nostrand Company, New York, N.Y.

Yehia, H.M. and Sebaee, E.Sh. (2012): Bioaccumulation of heavy metals in water, sediment and fish (Oreochromis niloticus and Clarias anguillaris), in Rosetta branch of the River Nile, Egypt. Afri. J. Biotech. 11(77):14204-14216.

Yousafzai, A. M., (2004): Toxicological effects of Industrial effluents dumped in River Kabul on Mahaseer, Tor putitora at Aman Garh industrial area Nowshera, Peshawar, Pakistan. Ph.D thesis, Department of Zoology, University of the Punjab, New Campus, Lahore, Pakistan.

Zaghloul K.H. (2000): Effect of different water sources on some biological and biochemical aspects of the Nile tilapia, Oreochromis niloticus and the Nile catfish, Claries gariepinus. Egypt. J. Zool., 34: 353-377. 
Zaki, M.S.; Authman, M.N; Hammam, A.M and Shalaby, S.I. (2014): Aquatic environmental pollution in the Egyptian country side and its effect on fish production. Life Sci. J., 11(9):1024 - 1029.

Zeidan, B. A.; Aly, A. I. M; Rashwan, I. M. H.; Ahmed, M.A. and Ghoraba, S.M. (2015): Scenarios for groundwater remediation using n15 in Nile Delta. Eighteenth International Water Technology Conference, IWTC18 Sharm ElSheikh.

\footnotetext{
ARABIC SUMMARY

تأثير بعض الملوثات على جودة المياه في ترعة الباجورية بمحافظة الغربية، مصر



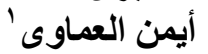

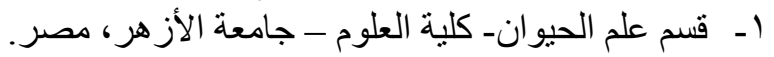

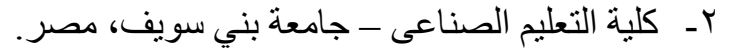

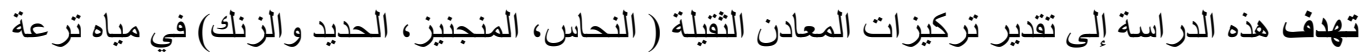

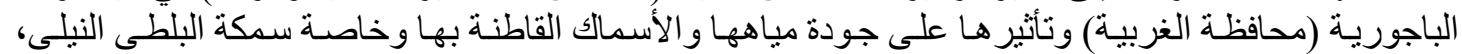

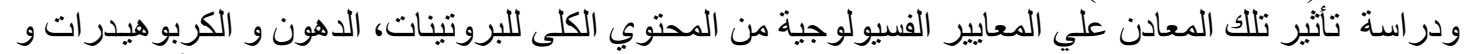
كذللك النشاط الإنزيمى لإنزيمى



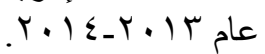



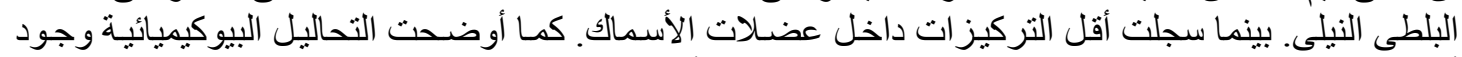

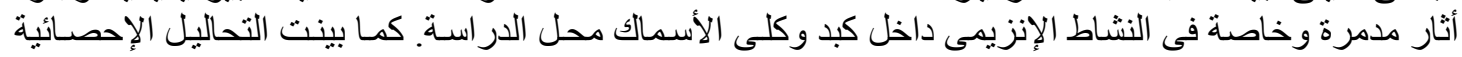

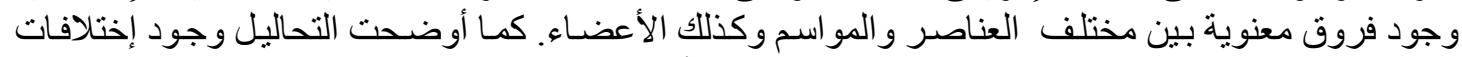
جو هرية بين مختلف القياسات الفسيولوجية وكذلك مختلف الأعضاء المختبرة خلال مو اسم الدراسة.
} 